\title{
Emotional Rhetoric \\ in Ælfric's Letter to the Monks of Eynsham
}

by

Edith Cherrett

A thesis submitted to the Faculty of Graduate and Postdoctoral Affairs in partial fulfillment of the requirements for the degree of

Master of Arts

in

History

Carleton University

Ottawa, Ontario

(C) 2018

Edith Cherrett 


\begin{abstract}
The Epistola Alfrici de consuetudine monachorum (Elfric's Letter to the Monks of Eynsham) is a monastic customary written in the form of a letter in $1005 \mathrm{CE}$ by Ælfric, a key figure in the Anglo-Saxon Benedictine sphere. Ælfric's Letter displays a powerful rhetorical strategy, by which Ælfric seeks to influence the emotional community of Anglo-Saxon monasticism in the eleventh century. This thesis explores his rhetorical use of pathos, ethos, and logos in the Letter to show that the layers to \#lfric's seemingly bland injunctions persuaded the reader, and displayed the emotional community he envisioned for Eynsham. I also argue that while Ælfric's audience was primarily the monks of Eynsham, the intended audience for this customary included a broader readership of reform-minded monks. The rhetoric presented in the Letter would have resonated with Ælfric's colleagues from his formative years at Winchester Abbey.
\end{abstract}




\section{Acknowledgements}

I would first like to thank my thesis advisor Dr. Marc Saurette of the History Department at Carleton University. The door to Professor Saurette's office was always open whenever I had a question about my research or writing. He consistently allowed this paper to be my own work, but steered me in the right direction whenever he thought I needed it.

I would also like to thank the professors who were sounding boards for this research project: Dr. Andrew Taylor of the University of Ottawa, and Dylan Wilkerson of the University of Toronto. I also greatly appreciate the joy of Latin and Old English imparted to me by Dr. Elizabeth Klassen and Dr. Robin Norris respectively.

I would like to acknowledge Ms. Elsie Liota as the second reader of this thesis, and I am gratefully indebted to her for her very valuable comments.

Finally, I must express my very profound gratitude to my husband for providing me with unfailing support and continuous encouragement throughout my years of study and through the process of researching and writing this thesis.

\section{Edith Cherrett}




\section{Table of Contents}

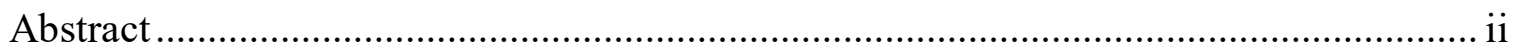

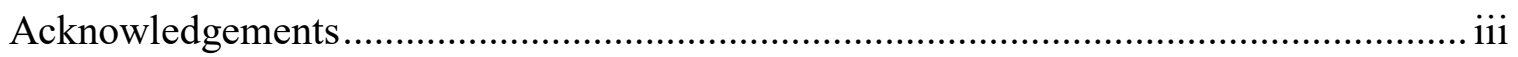

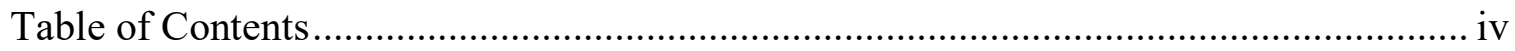

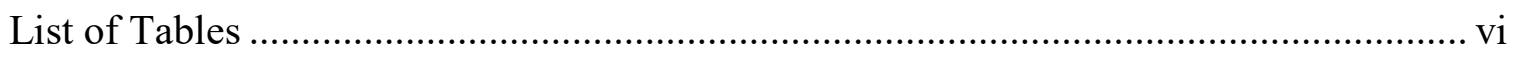

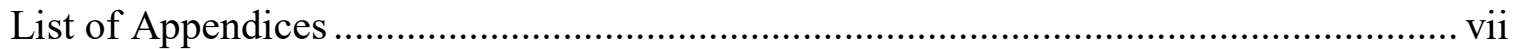

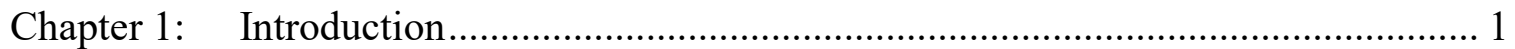

1.1. Ælfric of Eynsham: The Political, Social, and Religious Context ..................... 1

1.2. Emotional Rhetoric and Ælfric's Letter ................................................... 7

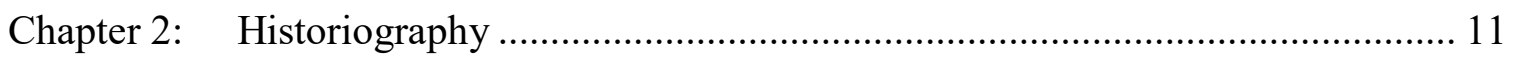

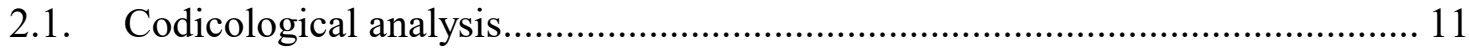

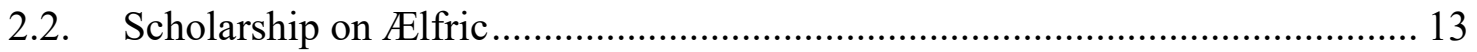

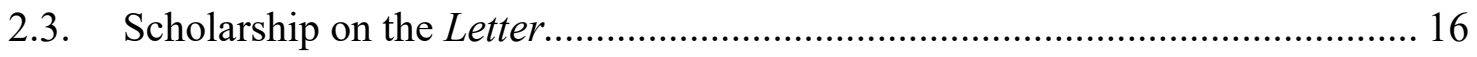

Chapter 3: Medieval Rhetoric and Emotion ........................................................... 19

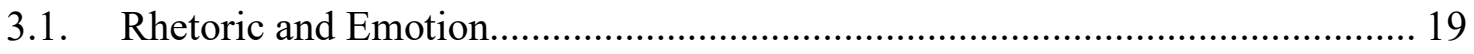

3.2. Recent work on the History of Emotion........................................................ 23

3.3. An Emotional Lexicon for Anglo-Saxon Benedictine Life ............................ 25

Chapter 4: The Use of Rhetoric in the Letter .......................................................... 28

4.1. Salutation - Sets the Tone for the Letter ..................................................... 29

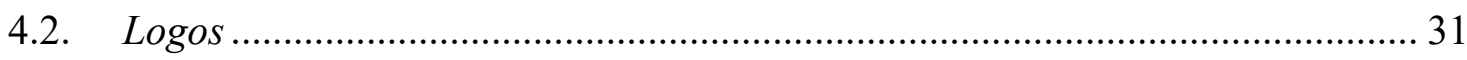

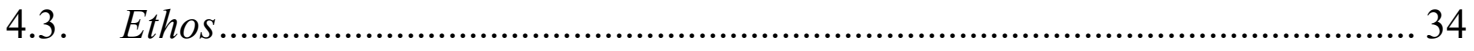

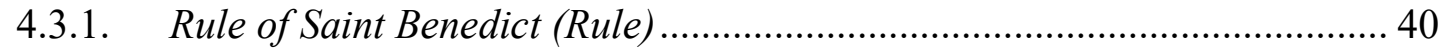

4.3.2. Regularis Concordia (Customary)........................................................ 41

4.3.3. Liber officialis (Amalarius)................................................................... 42

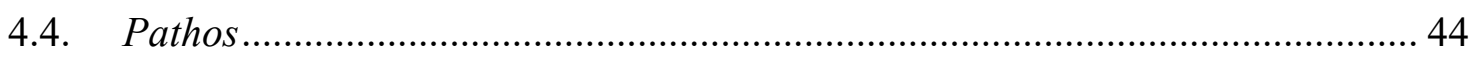

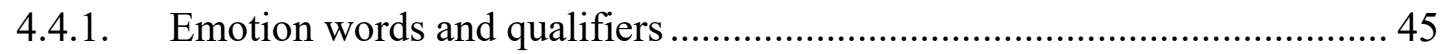

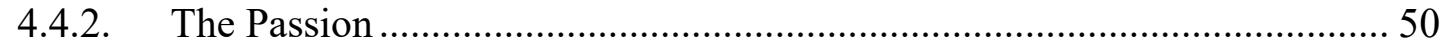

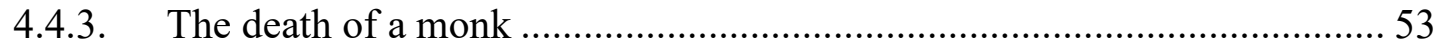

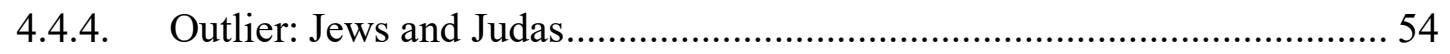

Chapter 5: Affecting the Emotional Community of Eynsham ................................. 56

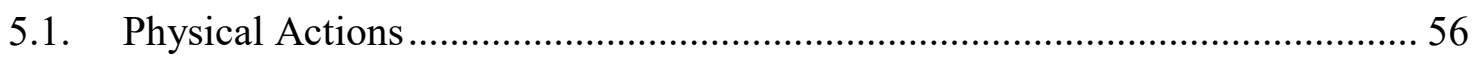




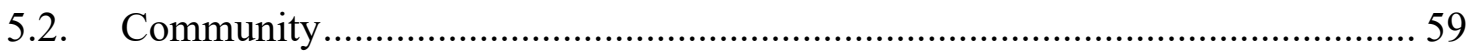

Chapter 6: Are the Monks of Eynsham a Fictive Audience? ..................................... 61

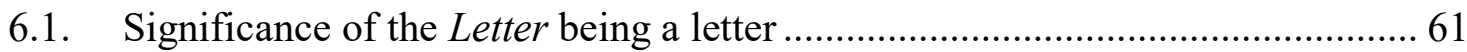

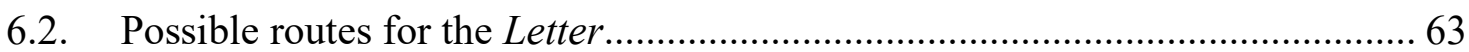

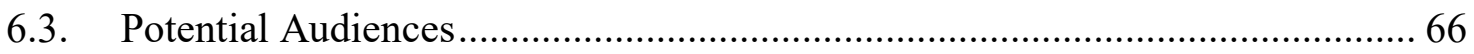

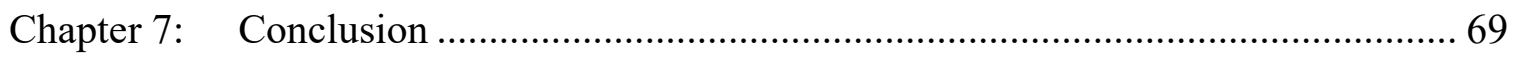

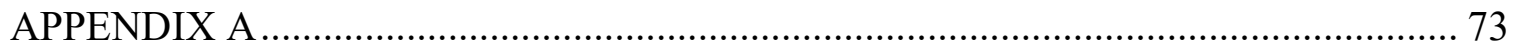

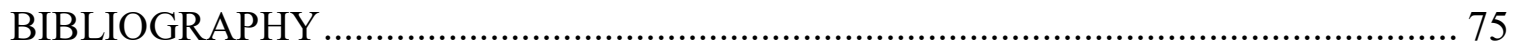




\section{List of Tables}

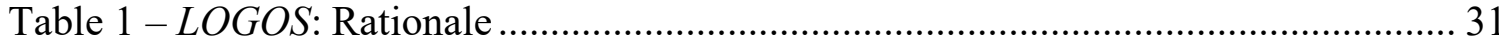

Table 2 - LOGOS: Because/Lest (Reason/Authority/Emotion) .................................... 32

Table 3 -ETHOS: Citing Authority: People ................................................................ 35

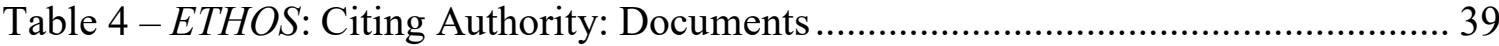

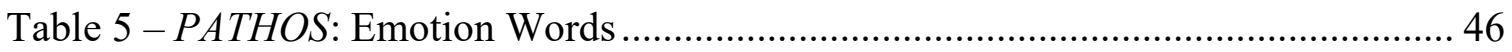

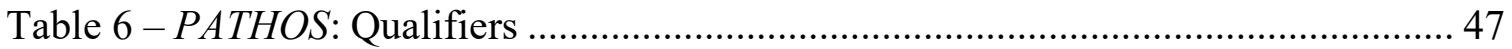

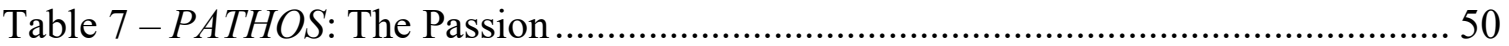

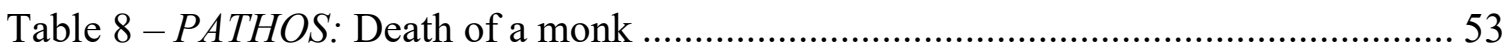

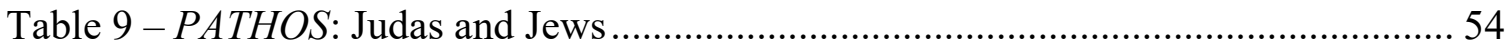

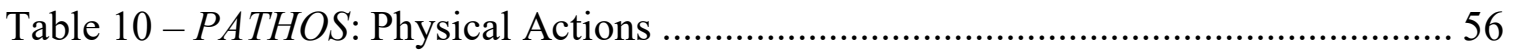

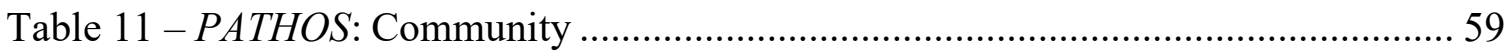




\section{List of Appendices}

Overview of the Works of Ælfric 


\section{Chapter 1: Introduction}

Monks are always wily. They like to change things without appearing to change things, using the guise of "reform" or "return to a former state" to implement innovations. In his letter to the monks of Eynsham, Ælfric uses an epistolary treatise to set customs for the house he would come to govern near the end of his life. My thesis explores how he makes his argument, and I argue that the Letter is a sophisticated persuasive text in which Ælfric communicates his rules for monastic life. The simplicity of the rules belies the complexity of the emotional model which underlies them. My thesis seeks both to understand Ælfric's rhetoric, and to discern the nature of the emotional community he was transmitting to his monks.

\subsection{Flfric of Eynsham: The Political, Social, and Religious Context}

Ælfric was born in Wessex circa $955 \mathrm{CE}$. He entered the Benedictine monastery in Winchester as a boy or young man where he studied in the 970 s and 980 s under Æthelwold ${ }^{1}$, one of the three authors of the Regularis Concordia. The Regularis Concordia was a consuetudinary or code of monastic law drafted in $973 \mathrm{CE}$ to supplement the Rule of Saint Benedict, a set of rules for monks living communally under the authority of an abbot, written around $530 \mathrm{CE}$ by Benedict of Nursia. ${ }^{2}$ Ælfric would have been a young monk in Winchester at the time of the drafting of the Regularis Concordia, and as a student of Æthelwold, Ælfric has been depicted by some as a

\footnotetext{
${ }^{1}$ Nicholas J. Higham and Martin J. Ryan, The Anglo-Saxon World (New Haven: Yale University Press, 2015), 354.

${ }^{2}$ Dom Thomas Symons, trans., Regularis Concordia, Anglicae Nationis Monachorum Sanctimonialiumque - The Monastic Agreement of the Monks and Nuns of the English Nation, (London: T. Nelson and Sons, 1953), ix.
} 
second-generation reformer of Benedictine monasteries. ${ }^{3}$ In $987 \mathrm{CE}$, Ælfric joined the newly founded monastery at Cerne Abbas, Dorset, Wessex. In $1005 \mathrm{CE}$, he became abbot of the newly founded monastery of Eynsham, where he died some few years later. ${ }^{4}$

To understand Ælfric, his writings, his motivations, and his rhetorical goals, I must situate them within the political, social, and religious milieu in which he lived and produced his work. Anglo-Saxon England in the second half of the tenth century was riven by political turmoil, with continual disruption to the royal order. Ælfric was a child during the short reigns of Eadred (946-955) and Eadwig (955-959), and joined the monastery at Winchester during the reign of Edgar (959-975). It was at the behest of this "blessed Edgar" that the Regularis Concordia was drafted in 973. The short rule of Edward (975-978) was then followed by the long reign of his half-brother, Æthelred (979-1016), who was the king for the rest of Ælfric's life.

From a social perspective, the king and nobles were intimately involved in the foundation of monasteries. Eynsham Abbey was one of the last religious houses founded by an Anglo-Saxon king. The foundation charter of Eynsham Abbey stated that King Æthelred "by the grace and mercy of God, king and ruler of the realm of the English gives authority to Æthelmær a man of outstanding loyalty to myself and very dear to me"

\footnotetext{
${ }^{3}$ Christopher Jones, "Flfric and the Limits of 'Benedictine Reform," in A Companion to Alfric, eds. Hugh Magennis and Mary Swan (Leiden: Brill, 2009), 70.

${ }^{4}$ Eynsham, Dorchester (Mercia) is some five miles northwest of Oxford (west of London), north of Winchester, which is northeast of Southampton, Portsmouth, and Cerne Abbas (Wessex). Caroline Louisa White, Ph.D., AElfric: A New Study of his Life and Writings (Boston, New York, and London: Lamson, Wolfee and Company, 1898), accessed December 11, 2016, https://archive.org/stream/Ælfricnewstudyo00whituoft/Ælfricnewstudyo00whituoft djvu.txt.

${ }^{5}$ From the first paragraph of the Letter, the salutation. Note that all references to the paragraphs of the Letter are based on the translation by Christoher Jones. Christopher A. Jones, AElfric's Letter to the Monks of Eynsham, (Cambridge: Cambridge University Press, 1998), 111.
} 
to establish a monastery "at an important place, hard by the river Thames and called Eynsham by those who live in that part of the country"6.

Ethelweard, an ealdorman beginning around the end of the reign of Edgar, and his son, Æthelmær, were patrons of Ælfric throughout his life. Both father and son were literate. ${ }^{7}$ Æthelmær had previously established Cerne Abbas Abbey in 987, and not only established Eynsham Abbey, but lived for a time with the new community (from 1005 to $1013 \mathrm{CE}$ ), possibly required to do so after falling out of favour at court. ${ }^{8}$ Eynsham was as important as Oxford at that time, and there had been a large church on the site for at least two hundred years. Fthelmær returned to favour and court circa $1013 \mathrm{CE}$, a date which is likely to have been subsequent to Ælfric's death.

The long reign of King Æthelred did not mean peaceful times as the Danes (also referred to as Vikings) continued to challenge in Anglo-Saxon England. The attacks by the Danes were a continuous source of fear for the Anglo-Saxon population at large. Monasteries were particular targets, as they were not defensively constructed, and often held items of value. Ælfric, and Benedictine monks in general, would have been constantly aware of the potential danger. In 997, the monastery at Horton, forty miles east of Cerne Abbas, was destroyed by Danes. In 1006, they attacked and destroyed the monastery at Reading, thirty-two miles east of Eynsham. In 1010, the monastery at Malmesbury, forty-two miles west of Eynsham was pillaged by the Danes, but managed

6 “Eynsham Abbey,” Eynsham Online, accessed December 10, 2016, http://eynshampc.gov.uk/org. aspx?n=Eynsham-Heritage\&id=287.

${ }^{7}$ J.A. Giles, Old English chronicles: including Ethelwerd's chronicle, Asser's Life of Alfred, Geoffrey of Monmouth's British history, Gildas, Nennius, together with the spurious Chronicle of Richard of Cirencester (London: G. Bell, 1906), vi.

${ }^{8}$ Malcom Godden, “Ælfric of Eynsham," in Oxford Dictionary of National Biography, accessed September 19, 2016, http://www.oxforddnb.com/view/10.1093/ref:odnb/9780198614128.001.0001/odnb9780198614128-e-187; jsessionid=7D4FAAA7ABC1BE0C81AFA605DA7ECA60. 
to recover. ${ }^{9}$ The continuing tension between Anglo-Saxon England and the Danes was demonstrated by the St. Brice’s day massacre in $1002 \mathrm{CE}$, when Æthelred ordered the mass killing of Danes living in England.

Despite changing kings, the disruption caused by the Danes, and patron ealdormen falling in and out of favour, the Anglo-Saxon Church enjoyed an influential position throughout this period. Benedictine monasteries were key to this prestige. Benedictine monasticism was based on the Rule of Saint Benedict, written by Benedict of Nursia circa $550 \mathrm{CE}$. The Rule delineated a monastic day filled with communal prayer, devotional reading and work. It provided for a busy, regulated life, simple and austere. ${ }^{10}$ Over the next few centuries, the Rule spread through Europe, not through a hierarchical organization, but rather through individual autonomous monasteries. ${ }^{11}$ Benedict may have visualized monasteries as religious retreats from the world; however they were tied to the secular world, attracted by monastic learning. Aristocratic families populated monasteries with their sons and daughters, in part due to social prestige, in part to control land and influence power. There was no sharp divide between secular aristocracy and the European church hierarchy, with many leading churchmen coming from noble or royal families. ${ }^{12}$ In addition, while individual monks or nuns vowed personal poverty, a monastery itself could acquire significant wealth and land. Eynsham Abbey, for example, was quite well off according to its cartulary which indicated that it was "endowed with

\footnotetext{
${ }^{9}$ David Knowles and R. Neville Hadcock, Medieval Religious Houses; England and Wales (London: St. Martin's Press, 1972), 70, 58, 59.

${ }^{10}$ Judith M. Bennett, Early Medieval Europe (New York: McGraw-Hill, 2011), 43.

${ }^{11}$ Higham and Ryan, The Anglo-Saxon World, 208. On the continent, Charlemagne and Louis the Pious had clearly supported the Benedictine Rule as the rule for monks. While some may suggest that the Anglo-Saxons, influenced by this prestige, also adopted this centrality of the Rule, I tend to agree with Higham and Ryan that at least in Anglo-Saxon England, there was greater autonomy. This autonomy can be exemplified in the proliferation of localized customaries.

12 Higham and Ryan, The Anglo-Saxon World, 208.
} 
the manors of Eynsham, Shifford, Shipton-on-Cherwell and Yarnton in Oxfordshire; Esher and Ditton in Surrey; Mickleton in Gloucestershire; and the church of St. Ebbe in Oxford with land adjoining" ${ }^{13}$ Monasteries were inextricably linked to local politics, and the individualism of monasteries became more apparent.

This blurring of secular and spiritual, and the involvement of nobles in the affairs of monasteries had long been a source of concern for Anglo-Saxon theologians. In his Letter to Bishop Egbert in $734 \mathrm{CE}$, the Venerable Bede proposed reform, lamenting the hypocrisy of those who founded pseudo-monasteries on their land for temporal benefits. ${ }^{14}$ In Bede's telling, noblemen founded and retired to monasteries, but lived lives of debauchery and sin, had wives, and had just 'become monks' to avoid military service. ${ }^{15}$ There is a question, of course, as to how much of Bede's rhetoric was simply in response to the growing tension between secular aristocracy and the religious hierarchy rather than his concern with licentious monks. The archbishops and bishops made several attempts to clarify both the activities of monasteries, and the relationship between the religious and secular. For example, in $747 \mathrm{CE}$, at Clovesho in England, the bishops and archbishops redefined the boundaries between the secular and ecclesiastical spheres.

The tension between secular and religious power, and changes within the AngloSaxon church over the tenth century led to calls for change by the late tenth century, change which was referred to as reform. Reform can mean different things to different people. In the monastic sphere, calls for reform could be used to highlight how a

\footnotetext{
${ }^{13}$ Herbert Edward Salter, Eynsham Cartulary (Oxford: Clarendon Press, 1907), vii. https://archive.org/details/eynshamcartular00saltgoog.

${ }^{14}$ Scott DeGregorio, ed., "Introduction," The Cambridge Companion to Bede (Cambridge University Press: Cambridge, 2010), 10.

${ }^{15}$ Higham and Ryan, The Anglo-Saxon World, 206.
} 
community or a society had fallen and how it needed to be brought back to what was often depicted as its original state. However, the notion of reform was also used as a catchall term for change. In this sense, reform movements aimed to make gradual changes rather than the rapid or fundamental changes which might characterize a revolution.

The tenth-century Benedictine reform in Anglo-Saxon England was informed by the ideology and practices of Cluny, founded by Duke William I of Aquitaine in 909/10. ${ }^{16}$ Influenced by the liturgical model and customary practices of this Burgundian monastery though contacts with the continent, English monastic reform was the result of existing social, political and religious pressures, the prosperity of the Anglo-Saxon economy, and through contact with the continent generated by trade, politics and religion.

This movement towards reform came to a head in $973 \mathrm{CE}$, when King Edgar summoned leading churchmen to the Council of Winchester to create the Regularis Concordia, a customary defining a unified Anglo-Saxon model of monastic practices. ${ }^{17}$ The lead drafters were Æthelwold, the Bishop of Winchester from 963 to 984, Dunstan, the Archbishop of Canterbury from 959 to 988, and Oswald, the Bishop of Worchester and Archbishop of York, until 992. The Regularis Concordia had two objectives: first, to ensure the observance of the Rule of St Benedict without interference by local aristocrats, and second, to emphasize the educational work of the monks, in particular, throughout

\footnotetext{
${ }^{16}$ Silvia Beltramo, "Medieval Architecture for Religious Tourism and Hospitality along the Pilgrimage Routes of Northern Italy," International Journal of Religious Tourism and Pilgrimage 3 (2015): 83. https://arrow.dit.ie/cgi/viewcontent.cgi?article=1042\&context=ijrtp.

${ }^{17}$ Dom Thomas Symons, trans., Regularis Concordia, Anglicae Nationis Monachorum Sanctimonialiumque - The Monastic Agreement of the Monks and Nuns of the English Nation, (London: T. Nelson and Sons, 1953), xxi.

"Regularis Concordia," British Library Online Gallery, last modified March 26, 2009, http://www.bl.uk/onlinegallery/onlineex/illmanus/cottmanucoll/r/011 cottiba00003u00003000.html.
} 
the newly revived monasteries of Anglo-Saxon England. ${ }^{18}$ Cerne Abbas, established in $987 \mathrm{CE}$, and Eynsham, established in $1005 \mathrm{CE}$, were two of these newly revived monasteries. It was upon becoming abbot of Eynsham that Ælfric wrote his Letter to the Monks of Eynsham.

\subsection{Emotional Rhetoric and Elfric's Letter}

The past twenty years have seen the rise in a new area of study, that of emotion in history. Historians of the emotions believe that culture shapes emotional life and that as a result, feelings vary across time and culture. ${ }^{19}$ In particular, I was inspired by the methodological work of Barbara Rosenwein in her book Emotional Communities in the Early Middle Ages and in her paper "Thinking Historically about Medieval Emotions."20

I was also very interested in the work by Lauren Mancia on the devotional culture of medieval monasteries in the eleventh- and twelfth-centuries, in particular her work on

\footnotetext{
${ }^{18}$ Note that the motivations and outcomes of monastic reform in Anglo-Saxon England in the tenth century have been viewed differently by historians over time. In the late nineteenth century (Frederick Tupper, Jr., "History and Texts of the Benedictine Reform of the Tenth Century," Modern Language Notes 8 (1893): 344.), the reform was seen as required by "the misbehavior of the canons. The causes lay in the Danish Invasion and the destruction of monasteries, which made possible the conversion of the conventual clergy into secular priests. An element of worldliness was thus introduced into the cloister life of England." By the mid twentieth century (Milton McC. Gatch, Preaching and Theology in Anglo-Saxon England: Alfric and Wulfstan, University of Toronto Press: Toronto, 1977, electronic copy.), monastic revival was more than simply reform, "the English movement was virtually a reintroduction of the regular life in a nation whose church had been secularized after the Danish raids". By the beginning of the twenty-first century (Christopher Jones, “Ælfric and the Limits of 'Benedictine Reform”, in A Companion to Alfric, edited by Hugh Magennis and Mary Swan, 67-108, Leiden, Netherlands: Brill, 2009, 68.), the view of Anglo-Saxon Benedictine reform was that it was more limited, worldly and internally diverse.

${ }^{19}$ Some recent names in the field of emotion history are: Susan J. Matt and Peter N. Stearns; Ute Frevert and Thomas Dixon; and, David Lemmings and Ann Brooks, all of whose work will be discussed more fully in the body of this paper.

${ }^{20}$ Barbara Rosenwein, Emotional Communities in the Early Middle Ages (Ithaca: Cornell University Press, 2006).

Barbara Rosenwein, "Thinking Historically about Medieval Emotions," History Compass 8.8 (2010): 828842.
} 
affective piety in her Yale university PhD dissertation entitled "Affective Devotion and Emotional Reform in the Eleventh-Century Monastery of John of Fécamp."21

Inspired by this literature, my thesis analyses an early eleventh-century document for its emotional rhetoric. Rhetoric is the art of using language, especially in public speaking, as a means to persuade. An emotional appeal is often effective as a rhetorical device. Producing an emotional appeal requires an understanding of one's audience and what may influence their emotions the most.

Abbot Ælfric wrote the Letter to the Monks of Eynsham circa 1005 CE. By analysing the Letter through the lens of emotional rhetoric, I will show how the broad policies of Benedictine reform were translated into the everyday practices of a monk. I also seek to locate the earlier echoes of twelfth-century affective piety.

While Ælfric has received considerable attention for his didactic and hagiographic writings in Old English and Latin, ${ }^{22}$ relatively few researchers have considered the Letter to the Monks of Eynsham. Over the course of a century, three major studies of the Letter have been written: Mary Bateson in 1892, Hadrianus Nocent and Kassius Hallinger in 1984, and Christopher Jones in 1998. These studies all focused on the Letter as a customary supplementing the dictates of the Regularis Concordia. ${ }^{23}$ The Regularis

${ }^{21}$ Lauren Mancia, "Affective Devotion and Emotional Reform in the Eleventh-Century Monastery of John of Fécamp," PhD diss., Yale University, 2013.

${ }^{22}$ Some of the more prominent names in Ælfric research would include: Peter Clemoes for his definitive work on “The Chronology of Ælfric's Work” in 1959; Milton McC. Gatch's work Preaching and Theology in Anglo-Saxon England: AElfric and Wulfstan in 1977; Malcolm Godden's work on AElfric's Catholic Homilies through the Early English Text Society (EETS) in various years such as 1979 and 2000; and, Hugh Magennis and Mary Swan's book A Companion to Alfric in 2009.

${ }^{23}$ Mary Bateson, "Excerpta ex Institutionibus Monasticis AEthelwoldi Episcopi Wintoniensis Compilata in usum Fratrum Egneshamnensium per Ælfricum Abbatem," Appendix 7 in Compotus Rolls of the Obedientiaries of St. Swithun's Priory, Winchester, edited by G. W. Kitchin, Hampshire Record Society 7 (London: Simpkin/Winchester: Warren, 1892), 171-198.

Hadrianus Nocent, in Consuetudimun Saec. Ed. Kassius Hallinger, Corpus Cons. Mon. 7.3 (Siegburg 1984), 149-185. http://www.thefreelibrary.com/Ælfric's+Letter+to+the+Monks+of+Eynsham.-a064976146. 
Concordia was a customary which was itself an augmentation of the Rule of St.

Benedict. ${ }^{24}$

Below, I provide a summary of the historiography of the Letter to the Monks of Eynsham, both in terms of a codicological analysis and as an overview of previous scholarship focus on Ælfric and the Letter. Ælfric's works are studied both as English literature and to provide a historical perspective of religion and Benedictine reform, although the interpretation of this reform has changed over the past century.

Next, I explore medieval rhetoric and the emotional lexicon for Anglo-Saxon Benedictine life. This step is required in order not to err by using present-day definitions and understandings of emotion. Building on the work on emotional communities in the early Middle Ages by Barbara Rosenwein, I develop an analytical framework of logos, ethos and pathos to analyse the emotional words and word patterns within the Letter. I discover that there are layers to Ælfric's emotional rhetoric; that which he used in the Letter itself to persuade the reader about changing practices (including a focus on certain events in the Benedictine calendar and life); and, that which pertained to the actions he was instructing be done, the emotional community he envisioned.

The use of rhetoric in Ælfric's Letter was a key strategy to reinforce the emotional and institutional order of Anglo-Saxon monasticism. He focussed on "a return to basics", that is, the humility and self-effacement of the Rule of Saint Benedict. There were some aspects of the Letter which one could interpret as leaning toward affective piety, such as the emphasis on the Passion and on the events surrounding the death of a monk. Emotion

Christopher A. Jones, Alfric's Letter to the Monks of Eynsham (Cambridge: Cambridge University Press, 1998).

${ }^{24}$ Regularis Concordia. CCCC MS 201 (Cotton MS Tiberius Aiii), The British Library.

Rule of Saint Benedict. Harley MS 5431, The British Library. 
however was used within the Letter first to persuade Benedictine monks in Anglo-Saxon England to accept some different customs and practices; and second, to conceptualize the monk's relationship with God in keeping with the Rule, as opposed to a stratagem of affective piety. My work in this paper provides a useful marker in time of the Letter, demonstrating that there had not been any major transition towards the affective piety of the twelfth-century, at least by Ælfric in this document.

As well as investigating how Ælfric incorporated emotional rhetoric in his Letter, I also explore how that rhetoric was disseminated. The monks of Eynsham may not have been the only intended recipients of this missive. The analysis of the rhetoric does indeed reveal that the arguments presented in the Letter were those which would have resonated with Ælfric's colleagues from his formative years as a monk at Winchester Abbey. Ælfric may have drafted this customary as a letter in order to share the contents as an open letter with various Benedictine monasteries along the route from Cerne Abbas Abbey in Wessex to Eynsham Abbey in Mercia. 


\section{Chapter 2: Historiography}

\subsection{Codicological analysis}

How has a copy of the Letter survived? Scarcely any medieval letters exist in their original form, so the absence of an autograph copy is typical. ${ }^{25}$ Our knowledge of letters mostly derives from the efforts of subsequent copyists and editors, who made copies from an epistolary register or collections maintained by authors such as Ælfric. In general, letters were copied and retained for two reasons. The first was the desire to promote and preserve a person's reputation by assembling and circulating a collection of his or her letters. The second was the need to provide students with models of how to write formal letters on topics and themes they might require. Certainly, the former reason seems likely for the Letter.

The sole surviving version of the Letter was in the possession of Archbishop Wulfstan, with whom Ælfric had corresponded about liturgical matters. It exists in a manuscript located in pages 237 to 257 of Cambridge, Corpus Christi College manuscript 265 (CCCC MS 265). ${ }^{26,27}$ CCCC MS 265 is entitled "Wulfstan's Handbook and other ecclesiastical extracts". This compilation is 276 folios long. Part A, from page 3 to page 268 is a group of manuscripts associated with Wulfstan, the bishop of London (9961002), archbishop of York (1002-23) as well as bishop of Worcester from 1002-16. CCCC MS 265, pages 3-208 were copied by a single scribe, while pages 209-15, 216-36 and 237-68 are separate booklets copied by several later scribes working at Worcester. It

\footnotetext{
${ }^{25}$ Lancaster University, "Medieval Primary Sources, Genre Rhetoric and Transmission, HIST424, Seminar III: Letters and Letter Collections," accessed December 11, 2016, http://www.lancaster.ac.uk/staff/haywardp/hist424/seminars/03.htm.

${ }^{26}$ https://parker.stanford.edu/parker/catalog/canvas-6436506590a697b36735433142710296

27 The odd pages of the manuscript were actually numbered in the upper right-hand corner at some point in the manuscript's life.
} 
is not clear exactly when part A was joined with these three booklets, or at what point two further booklets (pages 269-442 and pages 443-500) were added to the whole. The entire volume seems to have existed in its current state by the end of the thirteenth century $(1200 \mathrm{CE})$ at the latest. The majority of the volume is in Latin, excepting an Old English handbook on pages $72-83$. There are also some Old English additions to pages 41, 74, 77 and 78, which were made by Coleman, the chancellor and hagiographer of Wulfstan, Bishop of Worcester from 1062 until 1095. ${ }^{28}$

There are other versions of "Wulfstan's Handbook and other ecclesiastical extracts" (some of which were worked on by Wulfstan himself), but none of them contain Ælfric's Letter. In CCCC MS 265's version of this collection, Ælfric's Letter is immediately preceded by an abbreviated and adapted version of canon 145 of the 816 Council of Aachen (also known as the Institutio canonicorum) and is followed by Wulfstan's Sermon 8a and a work tiled De chrismate. ${ }^{29}$

The Letter is not in the same hand as pages 3-208. It is, however, in the same hand as the pages which follow it, pages 258-268.Thus, it was likely copied by another scribe at Worcester/York. Wulfstan valued the document enough to retain a copy of the Letter with his liturgical documents.

The codicological information concerning CCCC MS 265 is as follows. The manuscript contains extracts from a very large number of texts, mostly relating to ecclesiastical observance and penance. Pages 1 through 268 constitute a version of

\footnotetext{
${ }^{28}$ Cambridge, Corpus Christi College, Parker Library, CCCC MS 265, accessed December 10, 2016, http://dms.stanford.edu/catalog/CCC265 keywords.

29 “Ælfric: The Letters, Cambridge, Corpus Christi College, MS 265, pp. 3-208," University of Toronto, accessed December 10, 2016, http://groups.chass.utoronto.ca/Ælfric/MSC.html. Note that this website is a reference work in which the authors, Michael Elliot and Tristan Major, draw on numerous sources.
} 
"Wulfstan's Handbook", a compilation associated with Wulfstan the homilist (d. 1023), bishop of Worcester and archbishop of York, advisor and legislator for both Æthelred the Unready and Cnut. The bulk of the manuscript is eleventh-century, but it was added to into the twelfth century and beyond. ${ }^{30}$

The earliest reference to the Letter occurs on the verso of a parchment flyleaf bound at the beginning of the Letter manuscript itself (CCCC MS 265). A thirteenthcentury hand has added a brief table of contents, of which the fifth item is "Epistola Alfrici de consuetudine monachorum ${ }^{\prime \prime}$. This title is the first time we see the inclination to describe Ælfric's text as a letter. The next reference is in the sixteenth century, when Matthew Parker's Latin secretary and amanuensis, John Joscelyn (1529-1603), added a note to a different manuscript which indicates his recognition of the link between Ælfric's "epistola" and the "liber de consuetudine monachorum". Mention is also made by Humphrey Wanley (1672- 1726) and James Nasmith (1740-1808) when cataloguing Cambridge manuscripts. ${ }^{32}$

\subsection{Scholarship on Elfric}

Researchers study Ælfric both as an active participant in monastic reform and as an Anglo-Saxon writer. This duality of analysis can be exemplified in the differing entries in two reference dictionaries. Malcolm Godden’s entry for Ælfric of Eynsham in the Oxford Dictionary of National Biography in 2004 takes a British perspective, asking how Ælfric had an impact on British society. He highlights the theological impact of

\footnotetext{
30 "Cambridge, Corpus Christi College, MS 265: Wulfstan's Handbook and other ecclesiastical extracts," Stanford Libraries, Parker Library On the Web, Manuscripts In the Historic Parker Library at Corpus Christi College, Cambridge, accessed October 23, 2018, https://parker.stanford.edu/parker/catalog/nh277tk2537.

${ }^{31}$ University of Toronto, "\#lfric: The Letters."

32 Ibid.
} 
Ælfric's work concerning Eucharistic theory, particularly in the mid-1500s by an archbishop of Canterbury, thereby firmly situating Ælfric's work as an English contribution to Protestantism. ${ }^{33}$ David Yerkes' entry for Ælfric in the Dictionary of the Middle Ages in 1982 focusses on Ælfric’s style of writing Old English, referring to Ælfric as the finest prose stylist of the Anglo-Saxon Old English period. Yerkes discusses alliterating words, rhythmic prose, nominative participles and appositives causing difficulties in punctuating with no detail by way of content, intent or impact. According to Yerkes, Ælfric's use of closing strings of nominative participles and appositives make for difficult punctuating but good preaching: the text is difficult to read but easy to hear. ${ }^{34}$ While these two dictionary entries do not stand in for a deep literature review, the authors themselves are well known in their fields, and are representative of the two foci of analysis on Ælfric - historical and literary. My thesis on Ælfric's emotional rhetoric draws from both these camps, and further representatives will be discussed below.

Medieval letters, as with most writing at this time, were meant to be read aloud, whether reading to oneself or reading to an audience. Latin writing at this time, including the Letter, did not use spaces between words, so it was useful to sound out the phrases to understand the text. ${ }^{35}$ This oral and aural component to the Letter is an important point to keep in mind when analyzing its rhetoric. Rhetoric is the art of using language, especially in public speaking, as a means to persuade. As with his sermons, Ælfric is writing the

\footnotetext{
${ }^{33}$ Malcom Godden, "Ælfric of Eynsham."

${ }^{34}$ David Yerkes, "Ælfric," in Dictionary of the Middle Ages, vol. 1, Aachen-Augustinism, Joseph R. Strayer, ed. (New York: Scribner, c1982-c1989), 61.

${ }^{35}$ As I mention later in Chapter 5 on the format of a letter, following a format also aided in comprehension, so that the audience, learning Latin only as a second language, would know what to expect and in what order. Similarly, the format also aided the one who was reading the letter aloud.
} 
Letter with the intent that it be read aloud. He is tailoring the rhetoric for an oral presentation.

Scholars such as Yerkes (a Professor of English and Comparative Literature at Columbia University and a specialist in the history of the English Language) and Godden (an Emeritus Professor of Anglo-Saxon at the University of Oxford, specializing in Anglo-Saxon literature, especially Ælfric and the Alfredian writing) have shown that Ælfric was a prolific writer in both Latin and in Old English. ${ }^{36}$ Researchers estimate that his writings represent thirteen percent of all existing Old English texts. He wrote two sets of forty Catholic Homilies which were read to congregations in church on Sundays and feast days. He wrote three Latin works intended to aid students learning Latin: a grammar, a glossary, and the Colloquy, which is a text full of information about AngloSaxon life. He undertook translations of Old Testament books as well as two sermons attributed to Basil, and wrote letters to and on behalf of bishops and ealdormen. ${ }^{37}$

Ælfric and his works have been analysed from both historical and literary perspectives. From a historical perspective, he was "theologically conservative, and used interpretations of Augustine, Ambrose, Jerome, and Bede."38 From a literary perspective, his prose was "rhetorically brilliant, with heavy alliteration, balanced clauses, and a rhythmic sentence ending, or cursus." 39

\footnotetext{
36 For example: Malcolm Godden, ed. Alfric's Catholic Homilies: The Second Series, EETS, SS 5, (London: Oxford University Press, 1979).

David Yerkes, "Fifty-Six Ælfric Fragments: The Newly-Found Copenhagen Fragments of Ælfric's

'Catholic Homilies' with Facsimiles," Speculum 63 (1988): 890.

${ }^{37}$ For a list of Ælfric's works, see Appendix A.

${ }^{38}$ Malcom Godden, "Flfric of Eynsham."

${ }^{39}$ David Yerkes, “Ælfric,” 61.
} 


\subsection{Scholarship on the Letter}

As noted above, Ælfric's works demonstrate that he was primarily an educator. By the time he wrote the Letter in 1005, he had experienced a lifetime of practice conveying his concepts through the written word. His audiences were varied, from congregations of peasants to ealdormen (nobles), from young oblates to archbishops. When Ælfric wrote the Letter in 1005, the Regularis Concordia had been in use for thirty-two years. Ælfric had had the time to see the shortcomings of the text. The Regularis Concordia is a rather choppy document, agreed upon by committee in 973 CE, even if nominally written by Æthelwold. In 1005, upon becoming an abbot, Ælfric wrote a customary, addressed to the monks of Eynsham in the form of a letter. Did he perceive the appointment as abbot as an opportunity to create a customary seemingly to address the gaps or inadequacies as he perceived them in the Regularis Concordia? The three major studies of the Letter over the past century and a half have analysed the Letter in terms of its relationship to the Regularis Concordia.

In 1892, Mary Bateson produced the editio princeps of Ælfric's Letter to the Monks of Eynsham interpreting it as a key Benedictine reform document. ${ }^{40}$ She was the first researcher to study the Letter in depth, focussing on late Anglo-Saxon liturgical practices and the Letter's role as an aid to interpreting the Regularis Concordia.

In 1984, Hadrianus Nocent and Kassius Hallinger examined Ælfric's Letter in relation to continental customaries, continuing the interpretation that the main

\footnotetext{
${ }^{40}$ Mary Bateson, "Excerpta ex Institutionibus Monasticis Aethelwoldi Episcopi Wintoniensis Compilata in usum Fratrum Egneshamnensium per Ælfricum Abbatem," Appendix 7 in Compotus Rolls of the Obedientiaries of St. Swithun's Priory, Winchester, edited by G. W. Kitchin, Hampshire Record Society 7 (London: Simpkin/Winchester: Warren, 1892), 171-198.
} 
contribution made by Ælfric's Letter was its importance for the study of the Regularis Concordia. $^{41}$

In his 1998 study and translation, Alfric's Letter to the Monks of Eynsham, Christopher Jones compared the Regularis Concordia and the Letter, with their purpose to convey detailed instructions about the liturgy. He analyzed the Letter as a liturgical witness and its relationship to Ælfric's other works. Jones saw the Letter as a "vital document both as a rare witness to the life of a specific Anglo-Saxon monastery and as a significant item in Ælfric's canon."42

The aforementioned studies by Bateson, Nocent and Hallinger, and Jones all agree that the Letter clarifies the Regularis Concordia. The importance of the Regularis Concordia to the Anglo-Saxon movements to which Ælfric belonged is undeniable. I argue, however, that this reform document has overshadowed Ælfric’s own work and these three major studies seek only to interpret in light of other reform texts. My research, however, wishes to concentrate more on how this letter sought to address a particular audience and to speak to them with a particular rhetoric. To see the Letter as only a customary ignores the nuance of what Ælfric seeks to communicate in his epistolary text. Emotional rhetoric is embedded in an otherwise practical and consuetudinal text. I intend to take a new approach to analysing the Letter by looking at it through the lens of the history of emotion. By analysing the Letter from the perspective of emotion, we can see that in Ælfric's estimation, the 'reform' was a conservative return to a perceived previous way of existence, rather than a movement towards a new way of existence. By analysing

\footnotetext{
${ }^{41}$ Hadrianus Nocent, in Consuetudimun Saec. Ed. Kassius Hallinger, Corpus Cons. Mon. 7.3 (Siegburg 1984), 149-185. http://www.thefreelibrary.com/Ælfric's+Letter+to+the+Monks+of+Eynsham.-a064976146. 42 Jones, Elfric's Letter to the Monks of Eynsham, 2.
} 
the Letter's emotional rhetoric, can we see that there are few if any inklings of affective piety. Analysing the Letter's rhetorical content using a framework of pathos, ethos, and logos gives insights into the actual audience for this text. Ælfric had a broader audience in mind than the monks of Eynsham. Writing in the form of a letter gave Ælfric a vehicle to circulate his ideas. 


\section{Chapter 3: Medieval Rhetoric and Emotion}

\subsection{Rhetoric and Emotion}

Rhetoric is the art of persuasion. ${ }^{43}$ In Rhetorica, Aristotle said that emotional arousal was critical to persuasion, saying that "the orator persuades by means of his hearers, when they are roused to emotion by his speech; for the judgments we deliver are not the same when we are influenced by joy or sorrow, love or hate." ${ }^{44}$ Emotions can create beliefs and can increase or decrease the strength of those beliefs, emotions such as fear, guilt, anger, sadness, and disgust, or pride, relief and hope. Some emotions straddle the line between negative and positive, for example, empathy and compassion, which can be thought of as positive since they highlight others above ourselves, but which can also be considered negative as they can skew absolute moral judgement.

Our modern word 'emotion' derives from the mid-sixteenth-century from the French word émotion, from émouvoir 'to excite,' based on Latin emovere (from $e$ meaning 'out' and movere meaning 'to move'). ${ }^{45}$ Emotion is an affective state of consciousness in which joy, sorrow, fear, and hate, among others, is experienced, as distinguished from cognitive and volitional states of consciousness. ${ }^{46}$ It also connotes any of the feelings of joy, sorrow, fear, hate, love, etc.

\footnotetext{
${ }^{43}$ Aristotle, Rhetorica I, I.16.

http:/www.perseus.tufts.edu/hopper/text?doc=Perseus:text:1999.01.0060:book=1:chapter=2\&highlight=e motion

${ }^{44}$ Aristotle, Rhetorica I, II.5. Ibid.

45 “Emotion," English Oxford Living Dictionaries, accessed November 3, 2018, https://en.oxforddictionaries.com/definition/emotion.

"Emotion," Online Etymology Dictionary, accessed October 31, 2018, https://www.etymonline.com/word/emotion.

46 “All about Emotional Intelligence," University of Toronto, accessed October 23, 2018, http://psych.utoronto.ca/users/reingold/courses/intelligence/cache/about_ei.htm.
} 
Passion, on the other hand, derives from the Middle English, from Old French, from the late Latin term 'passio', chiefly a term in Christian theology relating to the suffering and death of Jesus, and from the Latin pati 'to suffer.' The Latin meaning relates to the etymology of the Greek word 'pathos', which means suffering, feeling, emotion, calamity, literally "what befalls one". Passion is defined as a strong and barely controllable emotion. ${ }^{47}$ Thus, when discussing the word emotion, it relates to the Latin term 'passio' and the Greek 'pathos'.

Pathos (frame of mind) is one of the three rhetorical strategies defined by Aristotle, the other two being logos (proof), and ethos (personal character of the speaker). ${ }^{48}$ Logos is a logical appeal. For example, a writer can use facts and figures to support his claims or thesis. Ethos is an appeal to the authority or credibility of the writer. One can do this, for example, by being a notable figure in the field in question; demonstrating mastery of the terminology of the field; or, being introduced by or producing bona fides from other established authorities. Pathos represents an appeal to the emotions of an audience. An emotional appeal uses the manipulation of the emotions rather than valid logic to win an argument. Using the rhetorical strategy of pathos, a writer attempts to win an argument by obtaining an emotional reaction from the audience.

The science of rhetoric continued to develop under the Romans. Cicero (106-43 $\mathrm{BCE}$ ) produced documents to aid in the development of a broad liberal education: $D e$ Inventione, De Oratione, and Topica. Quintilian (35-100 CE) expanded on Cicero's five

\footnotetext{
47 “Passion,” English Oxford Living Dictionaries, accessed November 3, 2018, https://en.oxforddictionaries.com/definition/passion.

"Passion," Online Etymology Dictionary, accessed October 31, 2018, https://www.etymonline.com/word/passion.

${ }^{48}$ Aristotle, Rhetorica I, II.8-14. Ibid.
} 
canons of rhetoric (invention, arrangement, style, memory and delivery) in his Institutio Oratoria. Although they are both Aristotle's heirs, Cicero and Quintilian generally treated emotion and reason as opposite poles within rhetoric. They agreed that an orator needed to study dialectic in order to discover and formulate arguments, but they did not want this part of the training to be overemphasized lest it result in excessive technicality and an unappealing display of skill. ${ }^{49}$

During the Middle Ages, two of the most influential works from the classical period were Cicero's De Inventione (On Invention) and the anonymous Rhetorica ad Herennium (the oldest complete Latin textbook on rhetoric). ${ }^{50}$ Cicero's De inventione became the shaping influence on medieval rhetorical teaching. "Both the De inventione and Rhetorica ad Herennium proved to be excellent, coherent teaching texts. Between them they conveyed complete and concise information about the parts of rhetoric, topical invention, status theory (the issues upon which the case rests), attributes of the person and the act, the parts of a speech, the genres of rhetoric, and stylistic ornamentation."

Note that while portions of Cicero's De Oratione were available as early as the ninth century, the entire manuscript was not discovered until 1421. There are two classes of manuscripts of the Orator, the Integri and the Mutili. The oldest representative of the latter group is the Codex Abrincensis (A), a ninth-century manuscript formerly in the monastery of Mont-St.-Michel and now in the library at Avranches. The manuscripts containing the whole of the Orator (Integri) are derived from a codex found in 1421 by

\footnotetext{
${ }^{49}$ Peter Mack, "Argument and Emotion in Troilus and Criseyde," in Medieval Rhetoric: A Casebook, ed. Scott D. Troyan (New York: Routledge, 2004), 117.

${ }^{50}$ Thomas Conley, Rhetoric in the European Tradition (Chicago: University of Chicago Press, 1990), 111.

${ }^{51}$ Rita Copeland, "Medieval Rhetoric," in Encyclopedia of Rhetoric, ed. Thomas O. Sloane (Oxford:

Oxford University Press, 2001), electronic version.
} 
Gherardo Landriani, bishop of Lodi, near Milan, and is named after the place of its discovery Codex Laudensis (L). It contained the De Inventione, the Ad Herennium, the De Oratore, the Brutus and the Orator. ${ }^{52}$

Augustine of Hippo's De doctrina christiana (completed in $426 \mathrm{CE}$ ) gave powerful official sanction to the Christian use of Ciceronian rhetoric. Cicero was the acknowledged rhetorician for encyclopedists, compendium writers, and grammarians who preserved the rudiments of the ancient art of discourse. ${ }^{53}$ Augustine justified the use of rhetoric to spread the doctrine of Christianity, stating that "After all, the universal task of eloquence, in whichever of these three styles, is to speak in a way that is geared to persuasion. The aim, what you intend, is to persuade by speaking." ${ }^{54}$

Boethius, (ca 480-524 CE), along with Aristotle and Augustine, was a fundamental philosophical and theological author in the Latin tradition. European rhetorical theory was influenced by his vision of classical rhetoric, putting rhetoric subordinate to philosophic argument or dialectic. ${ }^{55}$ Alcuin of York (735-804 CE) was also influenced by the works of Cicero and Augustine, developing his own work on rhetoric and dialectics. ${ }^{56}$ Anglo-Saxon literate culture was situated within this history of medieval rhetoric, and the Anglo-Saxon and Latin works of Ælfric in particular were situated within this tradition of rhetorical theological thinking.

\footnotetext{
${ }^{52}$ Cicero, Orator, LCL 342: 299. https://www.loebclassics.com/view/marcus tullius ciceroorator/1939/pb_LCL342.299.xml.

${ }^{53}$ James J. Murphy, Medieval Rhetoric: A Select Bibliography (Toronto: Centre for Medieval Studies, University of Toronto Press, 1971), 31.

${ }^{54}$ Augustine, De Doctrina Christiana, Book VI, 25.55 427, in Augustine in his Own Words, ed. William Harmless (Washington, D.C.: CUA Press, 2010) 139.

${ }^{55}$ Stanford Encyclopedia of Philosophy, s.v. "Anicius Manlius Severinus Boethius," last modified July 19, 2016, https://plato.stanford.edu/entries/boethius/.

${ }^{56}$ Matthew S. Kempshall, "The virtues of rhetoric: Alcuin's "Disputalo de rhetorica et de uirtutibus"," Anglo-Saxon England 37 (2008): 7.
} 
Elfric was fully acquainted with Latin rhetoric; he was able to exploit the native structures and vocabulary to permit variation and to leave aside or adjust the Ciceronian style to his own purposes. ${ }^{57}$ Elfric was also influenced by Jerome's prefaces to the Bible, as well as by prefaces by Augustine, Gregory, and Bede. ${ }^{58}$

Ælfric would have been well aware of Augustine's use of rhetoric to spread doctrine.$^{59}$ This awareness, combined with the evidence of his wide body of work, indicates that Ælfric was capable of using rhetorical strategies of logos, ethos, and pathos in furthering his discussions. In analysing the Letter, I argue that not only did he use these strategies, but he preferred pathos, emotion, as the strategy to frame his arguments. ${ }^{60}$

\subsection{Recent work on the History of Emotion}

The past twenty years have seen the rise of a new area of study, that of emotion in history. Historians of the emotions believe that culture shapes emotional life and that as a result, feelings vary across time and culture.

In 2014, Susan J. Matt and Peter N. Stearns produced "Doing Emotions History", a collection of essays which address topics centred on emotion history. For example, do emotions and emotional standards change when a society moves toward modernity? In

\footnotetext{
${ }^{57}$ Richard Hogg, An Introduction to Old English (Great Britain: Edinburgh University Press, 2002), 118. ${ }^{58}$ Jordan Zweck, Epistolary Acts: Anglo-Saxon Letters and Early English Media (Toronto: University of Toronto Press, 2018), 32.

${ }^{59}$ For example, in analysing Ælfric’s Sermones cathoici, Aaron J. Kleist states that C.L. Smetana notes that in Ælfric's work "there are the unmistakable turns of phrase that remind one of Augustine's rhetoric”, and that Malcolm Godden notes that "it is an Augustinian perspective that shows forth" in Ælfric's work. Aaron J. Kleist, Striving With Grace: Views of Free Will in Anglo-Saxon England (Toronto: University of Toronto Press, 2008), Kindle edition.
}

${ }^{60}$ While Ælfric used the constructs logos, ethos, and pathos in his writing, he would not have conceptualized his approach to rhetoric in these Aristotelian terms. I am using them as a framework to analyse Ælfric's rhetoric, as there is a strong link from Aristotelian concepts of rhetoric to Cicero to Augustine to Ælfric. Using a construct which is historic to Ælfric, in my opinion, strengthens the interpretation of his rhetoric. 
her chapter, Matt recalls the 1941 work of Lucien Febvre, who suggested that emotions of other eras and societies were so very different from those of the present day that their recovery required the scholar to abandon preconceived ideas about the emotions. ${ }^{61}$ This point is particularly applicable to understanding Anglo-Saxon Benedictine emotions. Analyzing tenth-century emotions requires building a different framework in which to understand the response of Benedictine monks to Ælfric's Letter.

The directors of two centres for the studies of emotions, Thomas Dixon, Mary University of London, and Ute Frevert, the Max Planck Institute for Human Development in Berlin co-edited the "Emotions in History" series, initiated in 2014. The series takes various perspectives on emotions by drawing on the history of science, medicine, psychology, literature, art, religion, politics, and economics. While contributions range across various time periods and reach across regional and national boundaries, there are limited studies applicable to medieval Anglo-Saxon Benedictine communities. Here again, there is a need to establish how one will go about assessing emotional responses to a document of the period.

Also in 2014, David Lemmings and Ann Brooks edited the collection of essays entitled "Emotions and Social Change: Historical and Sociological Perspectives". This volume focuses on changes in emotional regimes or styles and considers the intersection of emotions and social change, historically and contemporaneously. ${ }^{62}$ The main takeaway from this series of essays (for the purpose of this thesis) is that one must contextualize emotions within the historical and social milieu of the period.

\footnotetext{
${ }^{61}$ Susan J. Matt, "Recovering the Invisible: Methods for the Historical Study of the Emotions," in Doing Emotions History, ed. Susan J. Matt and Peter N. Stearns (Chicago: University of Illinois Press, 2014), 41. ${ }^{62}$ David Lemmings and Ann Brooks, eds., Emotions and Social Change: Historical and Sociological Perspectives (New York: Routledge, 2014), "Introduction".
} 
Barbara Rosenwein has explored the history of emotions, proposing that people lived in emotional communities, each having its own particular norms of emotional valuation and expression, as exemplified by cases from the Early Middle Ages. ${ }^{63}$ She has shown that different emotional communities coexisted, that some were dominant at times, and that religious beliefs affected emotional styles even as those styles helped shape religious expression.

Previous studies of Ælfric and his works were not grounded in the specific milieu of his emotional community. Rosenwein's work is useful as a model approach to conceptualize how to evaluate emotions in a community of Anglo-Saxon Benedictine monastery. She states that people live in emotional communities, each of which has its own particular norms of emotional valuation and expression. By analysing the Letter from the perspective of emotional rhetoric, we can understand Ælfric's concept of a monastic community, making Eynsham a microcosm of early eleventh-century AngloSaxon Benedictine monasteries at large.

\subsection{An Emotional Lexicon for Anglo-Saxon Benedictine Life}

Stephen Bann, in his book The Inventions of History: Essays on the Representation of the Past, argues that there is a difference between history and representation of history. Bann argues that the job of the 'New Historicist' is to see how literary representations reflect aspects of the social, political, economic, and cultural life of the time of the writer, and also how those writers comment on or critique them. ${ }^{64}$

\footnotetext{
${ }^{63}$ Barbara Rosenwein, Emotional Communities in the Early Middle Ages (Ithaca: Cornell University Press, 2006).

${ }^{64}$ Stephen Bann, The Inventions of History: Essays on the Representation of the Past (Manchester: Manchester University Press, 1990), 60.
} 
From a historical perspective, to understand a language is to gain insight into that culture and the process of integration that created it. It is important to consider why each word was chosen. The intent of the rhetoric of ancient Greece and Aristotle was logical reasoning. (It must be noted that while that may have been the intent, the Greeks said they were arguing using logic, but often they did not.) The rhetoric of ancient Rome and Cicero was full of flourishes, stories, metaphors, and the intent was to compel or persuade. Benedictine Anglo-Saxon rhetoric was for religious ends, to control the message and knowledge. (Augustine actually justified using rhetorical flourish if in the service of the good, but he drew the line at using it to lie.) In all three of these cases, rhetoric is still about persuasion.

The text of the Letter contains information concerning the emotional community of the author. For example, one can ask: did it make a difference that the monks were Anglo-Saxon; what emotions were monks or ordinary people expected to feel; and, how did they express their emotions in their words and in their writings? To answer these fundamental questions demands the construction of an emotional lexicon for the AngloSaxon, the Benedictine, and the monastic communities. This returns us to the work of Rosenwein and emotional communities. By analysing Ælfric's emotional rhetoric, we can define his emotional community.

Alice Jorgensen hint at the complexity of Anglo-Saxon emotional responses in her analysis of Ælfric's Life of St Agatha. The confrontation between the saint and her pagan persecutor has been characterized in terms of a "shame-rage spiral". Shame and rage mark the evil of the pagan. However, an Anglo-Saxon audience, attuned to issues of honour, shame and vengeance, might also feel some sympathy towards the pagan. As an 
audience identifies with the persecutor, the rebuke of the passio is even more pointed. The tenth-century audience would have been simultaneously sympathetic and rebuked whereas a modern audience may have only identified the negative aspects of the pagan. ${ }^{65}$

${ }^{65}$ Alice Jorgensen, "Historicizing Emotion: The Shame-Rage Spiral in Ælfric's Life of St Agatha," English Studies 93, no. 5 (July 2012): 529. 


\section{Chapter 4: The Use of Rhetoric in the Letter}

Elfric's Letter was a customary, a statement of restructured rules and duties, intended to facilitate Benedictine reform. Reform, as was discussed earlier, is often used as a catchall term for change, either back to a perceived previous way of existence, or towards a new way of existence. By examining Ælfric's use of rhetoric, we can accomplish two goals: first, to understand how Ælfric believed Benedictine monks in Anglo-Saxon England might be best persuaded to accept some different customs and practices; and second, to understand if Ælfric is moving back to some perceived 'way that things were' or is moving towards a new way of conceptualizing the monk's relationship with God, perhaps one based more on the emotions.

Rhetoric functions as a method of convincing, cajoling and manipulating. Aristotle's outline of logos, ethos and pathos forms a useful framework by which to analyze the text of the Letter. Ælfric used logos (rationale), ethos (authority), and above all, pathos (emotion). Amongst the details of changes to apparently minor monastic customs, Ælfric wove an emotional discourse - based on humility, reverence, and fear into seemingly dry instructions. Ælfric's Letter used written text to convince stubborn (or perhaps undisciplined) monks that there was need for change. As Milton Gatch noted, Ælfric believed

complete loyalty to Christ required complete and diligent submission of oneself to the orthodox tradition...in everything that he did his obedience to the Rule was implicit, and he worked as he did with a view to obtaining the reward promised those who renounced the world entirely and followed Christ with utmost faithfulness. ${ }^{66}$

\footnotetext{
${ }^{66}$ Milton McC. Gatch, Preaching and Theology in Anglo-Saxon England: Alfric and Wulfstan (Toronto: University of Toronto Press, 1977), 104.
} 
This approach, this submission to the Rule, would suggest that Ælfric's conceptualization of 'reform' was movement 'back to the way things were' rather than towards a new relationship based on emotion.

\subsection{Salutation - Sets the Tone for the Letter}

Ælfric's Letter follows the usual style of a letter, beginning with the salutatio, which begins with his name, the 'subscribed' format with the sender name first, since as Abbot he would have been socially ranked higher than the monks to whom he was writing. As the opening paragraph, the salutation sets the tone for the whole Letter, containing a dense use of ethos and pathos. The opening salutation is provided in its entirety as various components will be discussed below.

Abbot Ælfric to the brothers of Eynsham: Greetings in Christ. Behold, while dwelling with you I observe that, because you have recently been ordained to the monastic habit at Æthelmær's request, you need to be instructed in monastic customs by both the spoken and the written word. I am therefore setting forth in writing these few things from the customary that St Æthelwold, bishop of Winchester, together with his fellow bishops and abbots in the time of most blessed Edgar, king of the English, compiled from various sources and established for monks to observe, because until now the aforesaid little book has been unknown to your brotherhood. It is, I confess, with great trepidation that I presume to do so, nor do I dare to convey to you all those things that I learned about customs and usages while abiding for many years in his [Æthelwold's] school, lest you draw back at the strictness of so great an observance and not even wish to give me a hearing as I speak. Nevertheless, in order that you should not remain deprived of such salubrious teaching, I include in this document certain matters upon which our Rule does not touch. These I entrust to you to read, adding, too, certain points from the book of the priest Amalarius. I bid you health and happiness in Christ. ${ }^{67}$

The intent of the Letter is to persuade. Phrases in the salutation above, such as

"setting forth in writing these few things", "with great trepidation", "I do not dare", "you should not remain deprived", "salubrious teaching", and "I entrust you to read", are all

${ }^{67}$ Jones, AElfric's Letter to the Monks of Eynsham, 111. 
wording using pathos (emotion) to convince, cajole and manipulate rather than to command or demand. "Setting forth in writing these few things" tries to reassure the reader that there are only a few things that will need attention (despite the fact that there are some twenty pages of customary instructions). The next two phrases, "with great trepidation" and "I do not dare", emphasize how considerate and self-effacing Ælfric is making himself out to be. The use of these types of phrases is a textbook example of the use of modesty as ethos. He is setting himself up as the model monk he represents in the Letter, humble, learned, self-effacing. Yet, at the same time, Ælfric is making an appeal to his own personal authority by stating that he "learned about customs and usages while abiding for many years in his [Æthelwold's] school”. He has not just made the appeal to ethos of others (king, ealdorman, etc.) but also to his own authority. Ælfric uses rhetoric to be able to be humble and in authority at the same time. The two phrases, "that you should not remain deprived" and "salubrious teaching", emphasize how fortunate the readers are that they are being edified by the content of this Letter. The last phrase, "I entrust you to read", conveys to the reader the confidence that writer has in him.

The Letter ends with a short conclusio. "I bid you health and happiness in Christ, most beloved brothers." ${ }^{68}$ The closing in Latin is, "Valete feliciter in Christo, dilectissimi fratres". While this is a typical or stock closing formulae in Latin of the time, it still gives a sense of formality to the Letter itself. The effect of the conclusion is to present himself in one way emotionally and expect it to be the model elsewhere in the Letter. As we will see in the following analysis, Elfric's use of ethos and pathos continues to be the pattern in the body of the Letter, with limited use of logos.

${ }^{68}$ Jones, Elfric's Letter to the Monks of Eynsham, 150. 


\subsection{Logos}

Aristotle's definition of logos is an appeal to reason. In using logos, one needs to use a sound syllogistic argument, which is to say, the argument needs to be valid and all of its premises need to be true. ${ }^{69}$ I have identified on three examples of Ælfric's use of logos in the Letter, which are shown in the table below.

\section{Table 1 - LOGOS: Rationale}

\begin{tabular}{|l|l|}
\hline Para\# & \multicolumn{1}{c|}{ RATIONALE } \\
\hline 14 & $\begin{array}{l}\text { During the winter period the brothers shall be granted access to a fire, should } \\
\text { necessity require it; this shall not be done in the refectory, however. And } \\
\text { should the severe cold persist, let them all read and chant together in the } \\
\text { domus. }\end{array}$ \\
\hline 9 & $\begin{array}{l}\text { Begin the Office together and finish it together, all standing except for those } \\
\text { who are sick or undergoing bloodletting }\end{array}$ \\
\hline 57 & $\begin{array}{l}\text { The holy Rule says that, on summer nights, an interval is to be observed } \\
\text { \{between Nocturns and Lauds }, \text { but we who live in Britain, having shorter } \\
\text { nights in the summer than they do in Benevento, say that the four psalms we } \\
\text { sing for the king...are sufficient. }\end{array}$ \\
\hline
\end{tabular}

Elfric uses logos (logic or reason) sparingly in his Letter to explain the rationale of why monks should do certain actions. Two prominent uses of $\log o s$ are related to the fact that monasteries in England are physically located in a place where the climate and length of days/nights differ from that of Italy, where the Rule of Saint Benedict was created. The first of the two "location" arguments relates to the brothers being granted access to a fire during the winter months, should necessity require it, although the fire should not be in the refectory, but rather elsewhere. The distinction is interesting, as perhaps Ælfric does not want the monks to dawdle over their meal but supports the idea of reading and chanting together in the domus. The second "location" argument relates to

\footnotetext{
${ }^{69}$ Aristotle, Rhetorica, Ibid.
} 
short summer nights which limits the time available for the evening and nightly canonical hours. Ælfric indicates that a reduced number of psalms can be sung on summer nights, presumably in order that the monks do not become sleep deprived over the course of the summer. A third prominent use of logos relates to allowing certain monks who are sick or undergoing bloodletting not to stand during the Office. This presumably is to avoid disruptions of the Office from monks fainting or collapsing. These three uses of logos can be seen as a codification of common sense, as well as evidence of compassion.

The next table looks at instances where Ælfric uses logos with an explanation of why something should be done. Ælfric uses 'because' to introduce a clause expressing an explanation or reason. 'Lest' is used negatively with the intention of preventing something undesirable.

Table 2 - LOGOS: Because/Lest (Reason/Authority/Emotion)

\begin{tabular}{|l|l|l|c|}
\hline Para\# & \multicolumn{1}{|c|}{ BECAUSE } & Keyword(s) & R/A/E \\
\hline 24 & $\begin{array}{l}\text { Amalarius...At Nocturns we sing the psalm 'Our } \\
\text { God is our refuge' out of sequence, because the } \\
\text { Magi came to worship the Lord before he had } \\
\text { been baptized }\end{array}$ & Magi & R/A \\
\hline 29 & $\begin{array}{l}\text { The abbot...shall bless ashes and put them on the } \\
\text { heads of each and every person, because we read } \\
\text { in the Old and New Testaments that penitents } \\
\text { dusted themselves with ashes... showing that } \\
\text { human nation would return to dust, on account of } \\
\text { guilt for primordial transgression }\end{array}$ & R/A/E \\
\hline 39 & $\begin{array}{l}\text { On Maundy Tuesday chrism is to be blessed by } \\
\text { the bishop, because on that day the Lord passed } \\
\text { down to his disciples the sacraments of the church }\end{array}$ & $\begin{array}{l}\text { Lord passed } \\
\text { down }\end{array}$ & R/A \\
\hline 39 & $\begin{array}{l}\text { Because it is Jesus Christ we are proclaiming, as } \\
\text { Paul says... }\end{array}$ & Jesus Christ & R/A \\
\hline 43 & $\begin{array}{l}\text { Amalarius: Friday is the Parasceue (that is } \\
\text { 'preparation') of the Jews, because on that day the } \\
\text { Jews used to prepare necessities that they required } \\
\text { for the Sabbath, when they were not permitted to } \\
\text { work }\end{array}$ & Prepare & $\mathrm{R}$ \\
\hline
\end{tabular}




\begin{tabular}{|c|c|c|c|}
\hline Para\# & BECAUSE & Keyword(s) & $\mathrm{R} / \mathrm{A} / \mathrm{E}$ \\
\hline 46 & $\begin{array}{l}\text { The candle stands for the humanity of Christ, who } \\
\text { is truly acknowledged to be the light of the world }\end{array}$ & light & $\mathrm{R} / \mathrm{E}$ \\
\hline 46 & $\begin{array}{l}\text { Because the Bishop should anoint on the forehead, } \\
\text { where the high priest used to wear a plate of gold }\end{array}$ & Anoint & $\mathrm{R}$ \\
\hline 47 & $\begin{array}{l}\text { The cantor shall immediately begin the antiphon } \\
\text { with \{song\} because \{song\} should follow \{song\} } \\
\text { as in the secular Office }\end{array}$ & song & $\mathrm{R}$ \\
\hline 53 & $\begin{array}{l}\text { On the Octave of Pentecost, the liturgy should not } \\
\text { be repeated, because we should celebrate the } \\
\text { coming of the holy Week for seven days only }\end{array}$ & $\begin{array}{l}\text { Celebrate } \\
\text { only } 7 \text { days }\end{array}$ & $\mathrm{R}$ \\
\hline 70 & $\begin{array}{l}\text { Because you have asked, brothers, to have written } \\
\text { down for you how you are supposed to read or } \\
\text { sing in church through the course of the year, I } \\
\text { will explain... }\end{array}$ & $\begin{array}{l}\text { How to read } \\
\text { or sing }\end{array}$ & $\mathrm{R}$ \\
\hline Para\# & LEST & Keyword(s) & $\mathrm{R} / \mathrm{A} / \mathrm{E}$ \\
\hline 1 & $\begin{array}{l}\text { It is with great trepidation that I...dare to convey } \\
\text { to you all those things...lest you draw back at the } \\
\text { strictness of so great an observance and not even } \\
\text { wish to give me a hearing as I speak. }\end{array}$ & $\begin{array}{l}\text { Draw back } \\
\text { Not even } \\
\text { wish }\end{array}$ & $\mathrm{E}$ \\
\hline 20 & $\begin{array}{l}\text { lest they seem to be scurrying about irreverently } \\
\text { during the celebration of the Divine Office }\end{array}$ & Scurrying & $\mathrm{E}$ \\
\hline 80 & lest their worth appear diminished. & $\begin{array}{l}\text { Worth } \\
\text { Diminished }\end{array}$ & $\mathrm{E}$ \\
\hline
\end{tabular}

Ælfric uses these two conjunctions (because and lest) to initiate examples of logos, either straightforwardly or given with some explanation. In the three cases where he uses 'lest', he wished to prevent something: the monks avoiding strictness; scurrying about irreverently; and, worth being diminished.

With the word 'because', Ælfric indicates that he is explaining the information, for example, "because you have asked" (e.g., I am doing you a favour). He states that monks are not to repeat the "liturgy on the Octave of Pentecost", because "we should celebrate the coming of the holy Week for seven days only" (although he does not state why only seven days). He also states that the bishop should anoint on the forehead because this is "where the high priest used to wear a plate of gold" (e.g., tradition). The 
cantor shall immediately begin the antiphon with song A because song B should follow song $\mathrm{C}$, as it does in the secular office (this may be tradition, which is ethos/authority or it may be that there is a pattern to the songs which is $\log o s$ ).

Some examples of logos are combined with either ethos (authority) or pathos (emotion). For example, a certain psalm is to be sung out of sequence because the Magi came to worship the Lord before he was baptised, which combines logos with authority (i.e., the Magi did it). Similarly, on Maundy Tuesday the chrism is to be blessed by the bishop, because on that day the Lord passed down to his disciples the sacraments of the church (i.e., the Lord did it). These examples still tend to have the factual underpinning of a syllogistic argument.

On twenty-three occasions, Ælfric uses a logical construct (the 'because' clause) with an emotional rationale. The monks are to do a certain action because of reverence, sadness, guilt, humility, betrayal, wickedness, abandonment, departure, stripping, suffering, death, solemnity, laziness or sloth.

\subsection{Ethos}

According to Aristotle, ethos relates to the credibility of the writer or the reader. It can extend to the authority of others who can be cited or referenced. Ethos is an appeal to character or reputation. ${ }^{70}$ For example, to gain credibility in the eyes of the reader, you can begin by referring to your level of expertise, stating how many articles you have published, or how many awards you have received. Equally, you can downplay your accomplishments, showing modesty, to gain the trust of the audience. Another method is to find common ground with the audience so they identify with you. For this approach to

\footnotetext{
${ }^{70}$ Aristotle, Rhetorica, Ibid.
} 
work, the audience must have knowledge of, and a respect for, the accolades being mentioned or the authorities being cited.

Table 3 lists the names of numerous authorities which Ælfric cites in the Letter, including Æthelmær, Æthelwold, King Edgar, Augustine, and Pope Gregory. These authorities give both weight to Ælfric's Letter, as being grounded in expert opinions, as well as making the reader believe he is sharing in some special knowledge. Ælfric is positioning himself within a network of people to which he belongs. Each of these 'authorities' brings a different valuation to the Letter. As important as who Ælfric cites, is how he cites them.

Table 3 - ETHOS: Citing Authority: People

\begin{tabular}{|l|l|}
\hline Para\# & \multicolumn{1}{|c|}{ NAME OF AUTHORITY CITED } \\
\hline 1 & $\begin{array}{l}\text { AEthelmar } \\
\text { request, you need to be instructed in monastic customs by both the spoken and } \\
\text { written word }\end{array}$ \\
\hline & $\begin{array}{l}\text { AEthelwold } \\
\text { I am therefore setting forth in writing these few things from the customary that } \\
\text { St Æthelwold, bishop of Winchester...compiled from various sources and } \\
\text { established for monks to observe. }\end{array}$ \\
\hline 1 & $\begin{array}{l}\text { All those things that I learned about customs and usages while abiding for } \\
\text { many years in his [scil. Aethelworld's] schoool }\end{array}$ \\
\hline 1 & Edgar \\
\hline 8 & In the time of most blessed Edgar, king of the English \\
\hline 8 & Augustine/Saint Augustine \\
\hline 70 & Let him listen to what blessed Augustine says on the matter: \\
\hline 46 & Three [lessons] from St Augustine's exposition of the psalm \\
\hline Pope Gregory \\
\hline 47 & $\begin{array}{l}\text { Then shall follow the readings, with tracts and collects, according to the } \\
\text { arrangement of holy Pope Gregory }\end{array}$ \\
\hline & With three psalms as ordained by blessed Pope Gregory \\
\hline 13 & Experts \\
\hline & Because to the experts [song] and [song] do not seem worthily composed \\
\hline $\mathrm{x}$ & Miscellaneous \\
\hline $\mathrm{x}$ & Christ/Jesus \\
\hline & God/Lord \\
\hline
\end{tabular}




\begin{tabular}{|l|l|}
\hline Para\# & \multicolumn{1}{|c|}{ NAME OF AUTHORITY CITED } \\
\hline 39 & Paul - as Paul has said \\
\hline $\mathrm{x}$ & John / Gospel according to Saint John \\
\hline $\mathrm{x}$ & Saint Mary (BVM) \\
\hline
\end{tabular}

As an ealdorman, Æthelmær (ca. 960-1015 CE) would have commanded a certain level of respect in general in Wessex and Mercia. As the one who bequeathed the property of Eynsham, he would have been remembered even more positively by the monks. As well, there was the indication that Æthelmær would be residing with the monks, so another reason to be aware of his personage (although it is not certain whether Æthelmær's retirement to a monastery was due to piety or falling out with the king at court).

Ælfric's mentor Æthelwold (Bishop of Winchester 963-984 CE) is given the appellation of saint by Ælfric in the Letter, and is recognized in the Letter by Ælfric as an author of the 'customary' (Regularis Concordia). His bone fides therefore reside both in his position in the church as well as in the legacy he left behind. Ælfric also gains 'authority' or credentials as having been Æthelwold's student ('abiding for many years at his school'). These are both classic examples of attribution of ethos.

Ælfric refers to Edgar (ruled 943-975 CE) giving him the appellation of 'blessed king'. As Edgar was the king who called the synod to draft the Regularis Concordia, Ælfric is again giving authority to Æthelwold and the Regularis Concordia by naming the king under whom the document was drafted.

Ælfric bestows double honours on Augustine of Hippo (ca. 354-430 CE) with the appellation of both blessed and saint. The writings of Augustine certainly informed 
Ælfric's Letter (as well as other of his writings ${ }^{71}$ ) and citing this well-known Christian theologian lends weight and authority again to the Letter.

Gregory the Great (Pope Gregory 590-604 CE) sent the Roman mission to England to convert the population, and so was held in high regard by the Anglo-Saxons. Gregory is mentioned in the writings of both Bede and Alcuin, as well as by Ælfric on his second series of Catholic Homilies. ${ }^{72}$ He would have been well known and regarded by the monastic congregation. Gregory ranked the seven deadly sins as pride, envy, anger, sadness, avarice, gluttony and lust. ${ }^{73}$

Absent from the majority of the Letter are references to quotes from Biblical personages such as God/Lord, Jesus/Christ, the disciples, or the Blessed Virgin Mary. There is only one reference from Paul, where a quote is used to justify a certain procedure of actions. This limited use of Biblical citation is particularly noteworthy since the Rule of Saint Benedict contains numerous references to biblical verses. For example, the Prologue of the Rule refers to versus from the books of Romans, Psalms, Revelations, Isaiah, 1 Thessalonians, 1 Corinthians, 2 Corinthians, Matthew and Ezekiel. ${ }^{74}$ In his Letter, Ælfric support his arguments with references to religious works, such as Amalarius, the Rule, and the Regularis Concordia rather than to the primary source of the Bible and the words of Jesus or the Apostles. This point may support inquiries later in

${ }^{71}$ For example, Ælfric’s Catholic Homilies are English translations from Latin source authors, chiefly Augustine, Gregory the Great, and Bede. Andrew Scheil, “Ælfric of Eynsham,” Oxford Handbooks Online, accessed October 16, 2018.

http://www.oxfordhandbooks.com/view/10.1093/oxfordhb/9780199935338.001.0001/oxfordhb9780199935338-e-54

72 Joyce Hill, Ælfric, “Gregory and the Carolingians”, Brepols Online, 409, accessed June 13, 2018, https://www.brepolsonline.net/doi/abs/10.1484/M.TEMA-EB.5.102793.

${ }^{73}$ Of these seven, pride is the only one which figures in Ælfric's Letter, and only as represented by its antonym of humility.

${ }^{74}$ Rule of Saint Benedict, Prologue. 
this thesis as to whom the Letter is actually intended. Ælfric may believe that the arguments he is making will resonate more with his audience using support from theologians rather than Biblical quotations.

One of the most imprecise authorities cited is a vague reference to experts who prefer one type of hymn to another. The use of experts as a cited authority is an example of how Ælfric attaches the authority of a position (that of expert) to justify the argument he is making. In Ælfric's Letter, the reference to experts appears to carry the weight of opinion of a named authority.

Obtaining ethos by citing names of people is different from citing works (even if the cited people also wrote a cited document). By citing a person, you are attaching the authority of their position and status in society, such as ealdorman, bishop, king, saint, pope, or expert, as well as their attributes, such as knowledgeable, brave, or generous. In citing a document, it is usually the substantive argument within that document which is germane.

At the time when Ælfric wrote the Letter, three substantive and substantial texts existed to guide a monk's life, the Rule of Saint Benedict and the Regularis Concordia (customary) as well as the Liber officialis. Table 4 lists the citations of these three texts. It is informative to look at how Ælfric characterizes the references to these three texts. It is also instructive to look at what topics Ælfric discussed in his Letter, as these would have been areas where he believed customaries of the Rule and the Regularis Concordia were lacking or required emphasis or clarification. Even after the drafting of the Regularis 
Concordia, "many monasteries had their customary in which the life of the community would be closely detailed...A shared vocabulary could build up a common life." ${ }^{\prime 75}$

Table 4 - ETHOS: Citing Authority: Documents

\begin{tabular}{|c|c|}
\hline Para\# & NAME OF AUTHORITY CITED \\
\hline & Rule of Saint Benedict \\
\hline 1 & I include in this document certain matters upon which our Rule does not touch \\
\hline 2 & The holy Rule tells the rest \\
\hline 9 & $\begin{array}{l}\text { The custom of monks living under the Rule, does not permit any brother to be } \\
\text { negligent in attending the canonical hours }\end{array}$ \\
\hline 30 & $\begin{array}{l}\text {...thought it right in the days of Lent, as the holy Rule admonishes, to add } \\
\text { something to our divine service beyond the accustomed measure of our duty }\end{array}$ \\
\hline $\begin{array}{l}57 \\
*\end{array}$ & $\begin{array}{l}\text { The holy Rule says that, on summer nights, an interval is to be observed } \\
\text { \{between Nocturns and Lauds\}, but we who live in Britain, having shorter } \\
\text { nights in the summer than they do in Benevento, say that the four psalms we } \\
\text { sing for the king... are sufficient. }\end{array}$ \\
\hline 62 & $\begin{array}{l}\text { The holy Rule plainly admonishes that the brothers are to carry out the } \\
\text { Maundy every Saturday, but in addition to this the customary teaches that } \\
\text { every day, in a place suited to this purpose, the brothers should take turns } \\
\text { washing the feet...of paupers }\end{array}$ \\
\hline 62 & ...the Rule provides instruction concerning the treatment of guests. \\
\hline 63 & $\begin{array}{l}\text {...no layman shall have dominion over }\{\text { any }\} \text { monastery where the holy Rule } \\
\text { is observed, save the king alone }\end{array}$ \\
\hline & Customary (Regularis Concordia) \\
\hline 1 & $\begin{array}{l}\text { I am therefore setting forth in writing these few things from the customary that } \\
\text { St. Æthelwold... }\end{array}$ \\
\hline 26 & The customary says to give up lard from Septuagesima onwards. \\
\hline 28 & $\begin{array}{l}\text { From Quinquagesima onwards, the customary teaches to abstain from foods } \\
\text { made of milk or eggs. }\end{array}$ \\
\hline 29 & $\begin{array}{l}\text { The customary: on Ash Wednesday, after None has been sung, the abbot, } \\
\text { vested in a stole, shall bless ashes and put them on the heads of each and every } \\
\text { person }\end{array}$ \\
\hline 30 & $\begin{array}{l}\text { The customary: We have thought it right in the days of Lent, as the holy Rule } \\
\text { admonishes, to add something to our divine service... }\end{array}$ \\
\hline 33 & The customary teaches that on Maundy Thursday, ... \\
\hline 36 & The customary: After Sext one shall celebrate the mass for the poor... \\
\hline 37 & $\begin{array}{l}\text { The customary says that, if it be pleasing, after None they shall have ready the } \\
\text { figure of a serpent attached to a shaft... }\end{array}$ \\
\hline 40 & $\begin{array}{l}\text { The customary: After the celebration of mass all shall proceed to take the } \\
\text { mixtum... }\end{array}$ \\
\hline
\end{tabular}

\footnotetext{
${ }^{75}$ Aidan Bellenger, “A medieval novice's formation" in Medieval Monastic Education, eds. George Ferzoco and Carolyn Muessig (London: Leicester University Press, 2000), 39.
} 


\begin{tabular}{|l|l|}
\hline Para\# & \multicolumn{1}{|c|}{ NAME OF AUTHORITY CITED } \\
\hline 58 & $\begin{array}{l}\text { The customary teaches that the first bell for Nocturns and for Vespers always } \\
\text { ought to be rung for as long as it takes the schola to enter the church to pray. }\end{array}$ \\
\hline 60 & $\begin{array}{l}\text { The customary also teaches that there is to be an auditorium in the } \\
\text { monastery... }\end{array}$ \\
\hline 62 & $\begin{array}{l}\text { The holy Rule plainly admonishes that the brothers are to carry out the } \\
\text { maundy every Saturday but in addition to this the customary teaches that } \\
\text { every day... }\end{array}$ \\
\hline 63 & $\begin{array}{l}\text { The customary also warns that no layman shall have dominion over [any] } \\
\text { monastery where the holy Rule is observed... }\end{array}$ \\
\hline 1 & Amalarius (Liber officialis) \\
\hline 24 & ..certain points from the book of the priest Amalarius \\
\hline 26 & $\begin{array}{l}\text { Amalarius says: On Epiphany we omit the invitatory } \\
\text { nine weeks before Easter and ends on the Saturday after Easter }\end{array}$ \\
\hline 30 & Amalarius: In Lent a certain part of the fight is finished. \\
\hline 31 & $\begin{array}{l}\text { Amalarius: The days of the Lord's Passion are reckoned as the two weeks } \\
\text { prior to Easter. }\end{array}$ \\
\hline 32 & Amalarius: On Palm Sunday... \\
\hline 35 & $\begin{array}{l}\text { (wash altar on Maundy Tuesday) In this act, Amalarius says, we understand } \\
\text { that washing which Christ carried out among his disciples.... }\end{array}$ \\
\hline 37 & $\begin{array}{l}\text { Amalarius: At the ninth hour...new fire is to be struck...because the aforesaid } \\
\text { fire was extinguished in the fragile substance that descended from the first } \\
\text { man }\end{array}$ \\
\hline 43 & Amalarius: Friday is the [Sabbath] of the Jews \\
\hline
\end{tabular}

\subsubsection{Rule of Saint Benedict (Rule)}

Ælfric states in paragraphs one and two that he will include in his Letter those matters about which the "Rule is silent" and will not elaborate further on issues when "the Rule says the rest" (the "rest" being those topics which are presumably adequately covered by the Rule). The first addition he makes is to remark that the Rule does not permit any brother to be negligent in attending the canonical hours. This statement can be interpreted either that Ælfric has observed this practice in the past and wishes to comment on it overtly (which is ethos) or that he wishes to reinforce that monk should be dutiful, the antonym of negligent (which is pathos). The next reference is to adding something to 
the divine service beyond the accustomed measure of our duty. Again, here, Ælfric is referring to duty. The fifth reference to the Rule has been dealt with under logos. The sixth provides a compare and contrast between the Rule and the customary (regarding maundy, the washing of the feet of outsiders). This sixth reference reinforces not only humility, in washing feet of paupers for example, but provides confirmation that the provisions of the Rule can be expanded by the customary, and implicitly, by the Letter. He has also used the references to the Rule reinforce the attributes of humility and duty, which are part of pathos.

Thus, Ælfric has used the authority of the Rule of Saint Benedict to buttress his own authority. The text of the Rule makes his own text more authoritative. Similarly, he uses references from the Regularis Concordia.

\subsubsection{Regularis Concordia (Customary)}

After stating that he is going to set forth a few things from the customary, Ælfric does just that. Two of the references are prohibitions from eating certain foods from Septuagesima or Quinquagesima. Three references deal with changes/augmentations to the Rule, noted above. Six are procedural: two clarify actions on the specific days of Ash Wednesday (blessing ashes) and Maundy Thursday (logos of why certain responses/songs are sung/not sung), while four pertain to everyday actions (at Sext, None, first bell, after mass). One odd reference states that "the customary also teaches that there is to be an auditorium in the monastery". I wonder why there is a need to mention a physical room, unless Ælfric is trying to advise someone in advance that one will be needed (if writing the Letter prior to being at Eynsham) or admonishing someone that such a room does not exist (if writing the Letter after arrival at Eynsham). 


\subsubsection{Liber officialis (Amalarius)}

While Ælfric refers to 'Amalarius', he is actually excerpting from Amalarius' work, the Liber officialis, thus these references are included as document references rather than references to a person. The Liber officialis is cited nine times in the Letter, often with multi line references. Amalarius (ca. 775-850 CE), a liturgical writer from Metz, wrote the Liber officialis (On the Liturgy) which was one of the most widely read and circulated texts of the Carolingian era. ${ }^{76}$ Certainly this is supported by the fact that excerpts from Liber Officialis follow immediately after the Letter to the Monks of Eynsham in CCCC MS 265: Wulfstan's Handbook. ${ }^{77}$

Whether Ælfric knew of Amalarius from the abridgement of the third redaction of Amalarius' Liber officialis (a copy was available by the 930s at St Augustine's, Canterbury), or whether he worked from a variant version (such as Salisbury Cathedral MS 154), Ælfric is assuming that the reader of his Letter will be acquainted with the reputation of Amalarius himself, if not his work. ${ }^{78,79}$ Thus, Ælfric is using both the reputation/position of Amalarius as an authority, as well as using the authority of the text of the Liber to bolster and support his own authority.

In 1005, Amalarius was not a new theologian with ideas that would disrupt stodgy old monasticism; rather he was an old-school serious heavyweight whom everyone respected. By linking himself to Amalarius, Ælfric is positioning himself as a

\footnotetext{
${ }^{76}$ Amalar of Metz, On the Liturgy, Volume I, Books 1-2, ed. and trans. Eric Knibbs (Washington, D.C.: Dumbarton Oaks Medieval Library, 2014), flyleaf.

${ }^{77}$ Stanford Libraries, "Cambridge, Corpus Christi College, MS 265: Wulfstan's Handbook and other ecclesiastical extracts."

${ }^{78}$ Richard W. Pfaff, The Liturgy in Medieval England: A History (New York: Cambridge University Press, 2009), 88.

${ }^{79}$ Christopher Jones has done an analysis of Ælfric's use of Amalarius’ writings. Jones, Alfric's Letter to the Monks of Eynsham, 60-65.
} 
conservative. It may also be that Ælfric believes the arguments he is making will resonate more with his audience by using support from this particular theologian. 


\subsection{Pathos}

According to Aristotle, pathos is the appeal to emotion. A writer persuades the audience by making them feel certain emotions, including but not limited to love, pity, sorrow, affection, anger, fear, greed, lust, and hatred. ${ }^{80}$

Paul Thagard postulates that there are four kinds of power that result from emotional interactions. ${ }^{81}$ Coercive power encompasses threats, where the primary emotion is fear. Benefit power encompasses the prospect of potential gain, where the main emotion is desire. Charismatic power encompasses admiration where the main emotions are liking and trust. Norm power encompasses acquiescence, where the emotions are complex and can involve pride, guilt, shame, or even nested emotions such as fear of embarrassment or pride of obedience. ${ }^{82}$

Norm power is beneficial when the social norms serve the interests and needs of members of a society, for example by encouraging kindness and courtesy. The Letter is an example of norm power at work. An analysis of the text of the Letter can reveal the techniques Ælfric used in employing emotional rhetoric to persuade his audience.

I discovered that there were layers to the emotional rhetoric: the emotional rhetoric which Ælfric used in the Letter itself; the emotional rhetoric which pertained to the focus on certain events in the Benedictine calendar and life; and the emotional rhetoric which pertained to the actions he was instructing be done.

\footnotetext{
${ }^{80}$ Aristotle, Rhetorica, Ibid.

${ }^{81}$ Paul Thagard, "Power and Emotion", Psychology Today, August 2016, internet copy, https://www.psychologytoday.com/us/blog/hot-thought/201608/power-and-emotion.

${ }^{82}$ While this linking of power and emotion is a modern representation of theory, it is in line with medieval thoughts, for example, Augustines's support for the coercion of heretics, as found in his letter to Vincentius, Letter 93 V.17-19.
} 
Ælfric used emotional rhetoric in the Letter itself, in order to persuade the reader to accept changes to practices. He used emotional rhetoric in order to obtain an affective response from someone reading the letter.

Flfric also used emotional rhetoric in his conceptualization of the emotional community of the monks of Eynsham, the kind of emotional community being imagined by Ælfric in practice. In this case, the emotional rhetoric was in order to obtain the affective response of someone doing the actions described in the Letter.

Chronologically and cognitively, these two uses of emotional rhetoric are quite distinct. Chronologically, one happens during the reading of the Letter, while the other happens during the performance of the actions. D.G. Myers postulates that cognitively the major theories of emotion can generally be grouped into three main categories: physiological, neurological, and cognitive. Physiological theories suggest that responses within the body are responsible for emotions. Neurological theories propose that activity within the brain leads to emotional responses. Cognitive theories argue that thoughts and other mental activity play an essential role in forming emotions. ${ }^{83}$ In particular, both physiological and cognitive theories can be used to analyze Ælfric's words and instructions in his Letter to elicit emotions that will have an impact on the reader.

\subsubsection{Emotion words and qualifiers}

The words which Ælfric uses in the Letter are powerful tools to manipulate emotions. Reading an emotion word has a direct impact. The reader can immediately identify and experience the emotion being suggested.

${ }^{83}$ D.G. Myers, Theories of Emotion. Psychology: Seventh Edition (New York, NY: Worth Publishers, 2004), electronic version. 
I first analyzed the text by identifying the use of key noun emotion words themselves. I selected the words first based on Aristotle, Rhetorica ${ }^{84}$, then on the work of Barbara Rosenstein ${ }^{85}$ who created a medieval comparative lexicon for the monasteries of Trier and Clermont based on tombstone epitaphs from the seventh century in her book, Emotional Communities in the Early Middle Ages. I used these sources in order to define a lexicon based either on source material related to Ælfric, or source material somewhat contemporaneous to Ælfric. ${ }^{86}$ In general, words contained in titles, for example of psalms, hymns or collects, were ignored.

\section{Table 5 - PATHOS: Emotion Words}

\begin{tabular}{|c|c|c|}
\hline & \multicolumn{2}{|l|}{ Based on Aristotle $^{87}$} \\
\hline$\rightarrow$ & Love & 80 Most Beloved brothers - dulcissimus \\
\hline $\mathrm{x}$ & Fear & \\
\hline$\rightarrow$ & Guilt & $\begin{array}{l}29 \text { showing that human nature would return to } \\
\text { dust, on account of guilt for [man's] } \\
\text { primordial transgression }\end{array}$ \\
\hline $\mathrm{x}$ & Anger & \\
\hline$\rightarrow$ & Sad/sadness & $\begin{array}{l}22 \text { Sadness of the mothers lamenting their } \\
\text { [the Innocents] cruel slaughter }\end{array}$ \\
\hline $\mathrm{x}$ & Disgust & \\
\hline $\mathrm{x}$ & Pride & \\
\hline $\mathrm{x}$ & Relief & \\
\hline $\mathrm{x}$ & Hope & \\
\hline$\rightarrow$ & Joy & 62 same food the brothers enjoy \\
\hline & Based on Rosenwein (Table 4 & Trier and Clermont cemeteries ${ }^{88}$ \\
\hline $\mathrm{x}$ & Amor (love), amator (lover) & \\
\hline$\rightarrow$ & $\begin{array}{l}\text { Carus/carissimus } \\
\text { (dear/dearest), karissimi }\end{array}$ & 80 dearest brothers \\
\hline$\rightarrow$ & Caritas (love) & 42 serve the caritas to the brothers \\
\hline
\end{tabular}

\footnotetext{
${ }^{84}$ Aristotle, Rhetorica, Ibid.

${ }^{85}$ Rosenwein, Emotional Communities, 69-70.

${ }^{86}$ While Aristotle wrote in Greek some thousand years before Ælfric, I would make the case that there is a historical linkage of Aristotle to Ælfric through his rhetorical theory.

${ }^{87}$ Aristotle, Rhetorica, Ibid.

${ }^{88}$ Rosenwein, Emotional Communities, 69-70.
} 
Key Emotion Words [does not include a word in name of psalm, hymn or collect]

\begin{tabular}{|c|c|c|}
\hline $\mathrm{X}$ & Cupidus (greedy) & \\
\hline $\mathrm{X}$ & Dolere/dolor (sorrow) & \\
\hline $\mathrm{X}$ & Dulcissimus (sweetest) & \\
\hline$\longrightarrow$ & Felix (happy) & 80 I bid you health and happiness \\
\hline $\mathrm{X}$ & Flere (to weep) & [Cry only in the sense to say loudly] \\
\hline $\mathrm{X}$ & Furere/furor (to rage/rage) & \\
\hline$\rightarrow$ & $\begin{array}{l}\text { Gaudere/gaudium (to } \\
\text { rejoice/joy) }\end{array}$ & 28 without joy and happiness \\
\hline $\mathrm{X}$ & Invidus (envious) & \\
\hline $\mathrm{X}$ & Lacrimae (tears) & \\
\hline $\mathrm{X}$ & Planctus (lamentation) & [70 Only in title L. of Jeremiah] \\
\hline \multirow[t]{2}{*}{$\mathrm{x}$} & Solamen (solace) & \\
\hline & Other words & \\
\hline$\rightarrow$ & pleasure & 80 I am pleased \\
\hline
\end{tabular}

The goal was to identify emotion words which Ælfric used to covey a strong emotional message, such as in Jesus' commandment to 'Love your neighbour as yourself' (Matthew 22:39). Emotion words included: love, pity, sorrow, sadness, affection, anger, fear, greed, lust, hatred, guilt, disgust, pride, relief, hope, and joy. In actuality, however, Ælfric rarely (on only five occasions) used of noun or verb emotion words. This may have been due to Ælfric's style, which was literary as opposed to direct, rather than any lack of emotion.

I undertook a second word analysis based on the use of qualifiers, that is, how or in what manner the monks were to undertake activities and actions. This approach gained significantly more traction. The qualities expected of a monk are repeatedly reinforced.

\section{Table 6 - PATHOS: Qualifiers}

\begin{tabular}{|l|l|l|}
\hline Para\# & \multicolumn{2}{|c|}{ QUALIFIERS (Adjectives, or 'how' words) } \\
\hline 7 & Humbly & $\begin{array}{l}\text { Quality of being } \\
\text { humble, the opposite of } \\
\text { pride }\end{array}$ \\
\hline 68 & Humbly & \\
\hline 41 & humble & humiliate \\
\hline 26 &
\end{tabular}




\begin{tabular}{|c|c|c|}
\hline Para\# & QUALIFIERS (Adjectives, or 'hc & ' words) \\
\hline 31 & humility & \\
\hline 46 & Humanity of Christ, who is...the light of the world & \\
\hline 1 & recently & \multirow{9}{*}{$\begin{array}{l}\text { React right away, } \\
\text { diligence } \\
\text { Acting in a conditioned } \\
\text { manner }\end{array}$} \\
\hline 62 & regularly & \\
\hline 4 & Immediately & \\
\hline 47 & Immediately $(2 \mathrm{x})$ & \\
\hline 5 & immediately & \\
\hline 65 & finally & \\
\hline 62 & plainly & \\
\hline 68 & tirelessly & \\
\hline 9 & attentively & \\
\hline 13 & worthily & \multirow{5}{*}{$\begin{array}{l}\text { feeling or attitude of } \\
\text { deep respect with awe; } \\
\text { veneration }\end{array}$} \\
\hline 19 & from the depths of their hearts & \\
\hline 46 & reverently & \\
\hline 67 & reverently & \\
\hline 30 & fervently & \\
\hline 34 & silently $(2 \mathrm{x})$ & \multirow{4}{*}{$\begin{array}{l}\text { Self control and self } \\
\text { determination }\end{array}$} \\
\hline 33 & silently & \\
\hline 44 & inaudibly & \\
\hline 44 & In an audible voice & \\
\hline 64 & Reckless audacity (to attend an outside feast) & \multirow[t]{2}{*}{ Not obey, obey } \\
\hline 80 & Pleased that you have obediently agreed with me & \\
\hline
\end{tabular}

The word humble or its variant (humbly, humble, humiliate, humility) is used six times in the Letter and Ælfric reinforces this emphasis later in physical instructions that would elicit humility or humbleness. Being humble is a virtue, while its opposite, pride, is one of the seven deadly sins, a list formalized by Pope Gregory (whom Ælfric mentions in his Letter $)^{89}$. Humility is a strength, while pride is seen as weakness. A person who is humble is meek, deferential, respectful, submissive, diffident, selfeffacing. ${ }^{90}$ A humble person understands themselves, their limitations and their abilities.

\footnotetext{
${ }^{89}$ Given Ælfric's skill as a writer, it would seem likely that the reference to Gregory (and thus the allusion to the seven deadly sins) is by design rather than by serendipity.

${ }^{90}$ Oxford American Writer's Thesaurus, (New York: Oxford University Press, 2012), 436.
} 
They are able to take constructive criticism and counsel. Humble people understand their dependence on God and yield to Him. These are, in Ælfric's opinion at least, the attributes to be desired in a monk.

Ælfric continues to focus on desirable attributes for monks. As seen in Table 6 above, he uses words which relate to putting time constraints on actions - recently, regularly, immediately (four times), and finally. Here he is espousing diligence, the virtue that is the opposite of sloth. He also uses words to describe that actions should be done tirelessly, plainly and attentively. There is the sense here of conditioning, that is, the concept of muscle memory, where you do things so many times that you can do an action without even thinking. In this case, it is conditioning so that one does an action immediately.

Also shown in Table 6, Ælfric refers to obedience and its opposite, reckless audacity. In his closing, Ælfric remarks that he was "pleased that you have obediently agreed with me ${ }^{91}$. This concept of obedience is reflected in the required response to the Kyrie Eleison, which is 'Christ became obedient unto death' ${ }^{92}$ In these two examples, Ælfric is emphasizing the positive attribute in obedience to hierarchy, whether it be God or one's abbot.

On five occasions in the text of the Letter, Ælfric focusses on reverence ${ }^{93}$, using the words: worthily, from the depths of their hearts, reverently (twice), and fervently. Reverence is a feeling or attitude of deep respect with awe or veneration. Related to

\footnotetext{
${ }^{91}$ Paragraph 80 of the Letter. Christopher A. Jones, Alfric's Letter to the Monks of Eynsham, (Cambridge: Cambridge University Press, 1998), 149.

${ }^{92}$ Paragraph 33 of the Letter. Christopher A. Jones, Elfric's Letter to the Monks of Eynsham, (Cambridge: Cambridge University Press, 1998), 127.

${ }_{93}$ Oxford American Writer's Thesaurus, (New York: Oxford University Press, 2012), 755.
} 
reverence, on four occasions, Ælfric mentions "silently" or "inaudibly". This type of internalization of action shows self-control or self-determination, as there is no way to validate whether someone has silently recited a prayer or a psalm.

From my analysis of his emotional language, we see that Ælfric has emphasized specific qualities versus emotions; he expects a monk to be humble, diligent, obedient, and reverent. He has subtly appealed to the social norms which not only serve the interests and needs of members of the monastic society, but which will also save the souls of the monks.

\subsubsection{The Passion}

Ælfric used emotional rhetoric which pertained to the focus on certain events in the Benedictine calendar and life. It is instructive to look at what topics Ælfric discussed in his Letter, as these would have been areas where he believed the Rule and the customary were lacking or required emphasis. Ælfric spends 20 paragraphs on activities during the Passion (the two weeks before Easter), 25 if one includes the paragraphs relating to the nine weeks leading up to and including Lent (paragraphs 26-50) which represents 31 percent of the Letter. In contrast, the next most deliberated topics are nine paragraphs discussing activities during Advent/Christmas/Epiphany (paragraphs 16-24) which is 11 percent of the Letter, and five paragraphs discussing activities around the illness and death of a monk (paragraph 65-69) which is six percent of the Letter. Table 7 identifies the citations of the Passion by Ælfric in the Letter.

Table 7 - PATHOS: The Passion

\begin{tabular}{|l|l|}
\hline \multicolumn{2}{|c|}{ EMOTION KEYWORD - Passion/Suffering } \\
\hline Para\# & Passion \\
\hline 13 & In Passiontide at Vespers \\
\hline 30 & Of the Lord's Passion \\
\hline
\end{tabular}




\begin{tabular}{|c|c|}
\hline \multicolumn{2}{|r|}{ EMOTION KEYWORD - Passion/Suffering } \\
\hline Para\# & Passion \\
\hline 31 & $\begin{array}{l}\text { Days of the Lord's Passion...two weeks prior to Easter/Approach the Passion } \\
\text { of Christ in humility/two weeks of Christ's Passion/two prior ages Christ's } \\
\text { Passion was foretold }\end{array}$ \\
\hline 32 & The Lord's Passion/that Passion \\
\hline 39 & Drank the cup of his Passion \\
\hline 43 & The Lord's Passion/in the same Passion reading/at the conclusion of Passion \\
\hline 70 & $\begin{array}{l}\text { Passiontide, that is, for the two weeks before Easter/... is not to be sung except } \\
\text { on [Passion] Sunday/Passion Sunday }\end{array}$ \\
\hline 73 & We read lives or passions of the saints \\
\hline & Suffer/suffering/suffered \\
\hline 39 & On the day the Lord suffered \\
\hline
\end{tabular}

The Passion, as Ælfric himself notes several times in the Letter, is the two-week period prior to Easter, and relates to the suffering and death of Jesus Christ. In referencing the Passion, Ælfric focusses on Christ crucified, as opposed to Christ in majesty, thereby highlighting Christ's suffering and sacrifice. From a cognitive theory approach, thinking about Christ's suffering and death can bring about an emotional response, for example, empathy, sorrow, pity, sadness, or thankfulness. Within an analysis of only one document, it is impossible to ascertain whether Ælfric is reinforcing the way the monks celebrate the Passion, or if he is asking his monks to change how the Passion is celebrated. But by asking them to consciously remember the mournful nature of the time period, he is creating an emotional response, one that is sad. He is thus implicitly reinforcing the attributes he has explicitly developed in his use of qualifiers.

Not only does Ælfric refer to the Passion in nine different paragraphs, but in four of those paragraphs he using the literary device of conduplicatio, the repetition of a word or words in adjacent phrases or clauses, either to amplify the thought or to express emotion. He emphasizes the impact of the Passion, referring to Amalarius' use of the word itself four times in paragraph 31, while in paragraph 43, the word Passion occurs 
three times. Unfortunately, a close reading/parsing of any of the paragraphs (in order to analyse the emotional balance, for example) is not useful, as Ælfric is paraphrasing the sentiments of Amalarius in these passages, which alters the tone of the voice.

Nonetheless, the fact that Ælfric felt the need to reinforce the emotion of the Passion with so many repetitions is noteworthy.

Certain references to actions hold double purpose. Cognitive theory holds that just thinking about uncomfortable situations can bring about the emotional response of misery. ${ }^{94}$ Physiological theory suggests that responses within the body are responsible for emotions. ${ }^{95}$ Thus, by stating a certain action, such as going barefoot or being prostrate, Elfric gains an immediate emotional response when the information is read in the Letter (cognitive), and a later emotional response when the action is undertaken (physiological). While actions will be dealt with in the next section, two examples are given here to demonstrate the duality of purpose.

For example, on Good Friday, the monks were to go barefoot, a condition which could be physically unpleasant in England in March. Thinking about this discomfort could cause an emotional response, be that fear, dismay, sadness, or anger.

In another example, the three days when the monks say the liturgy while prostrate (laying face-down on the floor or ground) are the days leading up to and including the Crucifixion and Christ's sojourn in hell. Thinking about being in an uncomfortable position while thinking about Christ's suffering can also cause an emotional response, such as sadness, anxiety, guilt, or empathy.

${ }^{94}$ D.G. Myers, Theories of Emotion, electronic version.

${ }^{95}$ D.G. Myers, Ibid. 


\subsubsection{The death of a monk}

Ælfric spends five paragraphs, six percent of the text by paragraphs, discussing activities around the illness and death of a monk. It is unlikely that Ælfric juxtaposed the topics of the death of Christ and the death of a monk by accident. It is more likely that he wanted to emphasize one's own mortality, and the debt that man owes to Christ. Table 8 gives the references to death of a monk by Ælfric in the Letter.

Table 8 - PATHOS: Death of a monk

\section{EMOTION KEYWORD - Death of a Monk}

\begin{tabular}{|c|c|}
\hline Para\# & Reference \\
\hline 65 & $\begin{array}{l}\text {...the eucharist, candles and a thurible to visit the sick man, singing penitential } \\
\text { psalms, followed by a litany, prayers and an anointing with } \\
\text { oil...then...communion }\end{array}$ \\
\hline 65 & It [visitation] shall be carried out until his death \\
\hline 66 & On the verge of death... all shall assemble to keep watch at his passing \\
\hline 66 & $\begin{array}{l}\text { Once the man is dead - body washed, body clothed in clean garments... borne } \\
\text { into the church while all chant... if he cannot be buried on that same day...they } \\
\text { shall keep watch around the body overnight }\end{array}$ \\
\hline 67 & $\begin{array}{l}\text { As the brothers return from the burial, they shall begin seven psalms and } \\
\text { finish these prostrate in choir, adding Lord's Prayer and a collect }\end{array}$ \\
\hline 67 & $\begin{array}{l}\text { Then for the next seven days at the end of every hour they shall prostrate } \\
\text { themselves and sing... }\end{array}$ \\
\hline 67 & ...up to the thirtieth day, Vigils of three lessons shall be said for him \\
\hline 67 & $\begin{array}{l}\text { Every single priest shall reverently celebrate thirty masses for the soul of the } \\
\text { deceased brother, and the other brothers are to assist [his soul] as much as they } \\
\text { are able by reciting the psalms }\end{array}$ \\
\hline 68 & $\begin{array}{l}\text { A letter shall be sent to all the neighbouring monasteries to make known the } \\
\text { date of his burial. Whereas the fate of that irrevocable hour lies in store for all } \\
\text { Lord has deigned to call from the prison of this world } \\
\text { We humbly beg that you would tirelessly intercede to the Lord on his behalf }\end{array}$ \\
\hline 69 & $\begin{array}{l}\text { [when] word comes that some brother from another, familiar monastery has } \\
\text { dies...chant fifteen gradual psalms for his soul }\end{array}$ \\
\hline 69 & $\begin{array}{l}\text { Some brother from an unknow monastery has died... a single day's } \\
\text { commemoration shall be performed }\end{array}$ \\
\hline 69 & $\begin{aligned} & \text { Prayer on behalf of a brother who has died } \\
& \text { - } \text { Blessed Mother of God } \\
& \text { - } \text { Holy confessor Benedict } \\
& \text { - } \text { Fervent supplication } \\
& \text { - } \text { Mercy for which we pray } \\
& \text { - } \text { Not permit him to be tormented by the flames of hell } \\
&\end{aligned}$ \\
\hline
\end{tabular}


As another example of how one action can serve dual purposes, it should be noted that the monks are also required to be prostrate while saying psalms for the death of a fellow monk, and while performing confession. Physiological theory states that emotional responses to physical reactions are situational. ${ }^{96}$ Prostration during confession could result in the emotion of contrition or guilt, while in the case of the death of a fellow monk, it could result in fear, dread, foreboding, or sadness.

\subsubsection{Outlier: Jews and Judas}

Particularly harsh emotional language appears in the Letter in reference to Judas and Jews, as the betrayer and deniers of Jesus. On the two occasions, in paragraphs 39 and 43, when Ælfric refers to Judas and/or the Jews, his language contains strong negative words: treacherous, derided, mocked, false, betrayed, punishment, and guilt. Nowhere else in the Letter does Ælfric use such strong negative emotions. Table 9 list the three times when Ælfric refers to Judas or Jews.

\section{Table 9 - PATHOS: Judas and Jews}

\begin{tabular}{|l|l|}
\hline Para\# & \multicolumn{1}{c|}{ Judas, Jews } \\
\hline 43 & $\begin{array}{l}\text { All the orations should be performed with genuflexions, except for the one } \\
\text { wherein we pray for the treacherous Jews. For they derided and mocked Christ } \\
\text { by going down on bended knee before him, saying 'Hail, king of the Jews. }\end{array}$ \\
\hline 39 & $\begin{array}{l}\text { On Maundy Tuesday, Good Friday and Holy Saturday we do not exchange the } \\
\text { peace, on account of the kiss of false peace by which Judas betrayed Christ. }\end{array}$ \\
\hline 43 & The collect 'O God, from whom Judas [received the punishment of his guilt]. \\
\hline
\end{tabular}

Through this strong emotional language, Ælfric is building a picture for his audience of the negative attributes of non-believers. Ælfric appears to have moved away from Augustine's position of pity towards the Jews to one of disgust and animosity.

\footnotetext{
${ }^{96}$ D.G. Myers, Theories of Emotion, electronic version.
} 
Through exemplifying Judas and Jews in general as non-believers, Ælfric is reinforcing that according to the Rule of Saint Benedict, the highest accomplishment of a monk was to live his life out of a perfect love for God ${ }^{97}$, while a less perfect monk would be governed by a fear of God's punishment. Ælfric appears to be demonizing outsiders (Jews) in order to strengthen his idea of proper practice.

${ }^{97}$ Rule of Saint Benedict, chapter 7. 


\section{Chapter 5: Affecting the Emotional Community of Eynsham}

Cognitive theory tells us that reading or hearing about uncomfortable actions can trigger an emotional response, and doing the actions can trigger an emotional response from a physiological theory perspective. ${ }^{98}$

\subsection{Physical Actions}

Ælfric covers a wide range of required actions in his Letter, including prostration, going barefoot, standing, kneeling, genuflecting, rising, sitting, washing feet, placing ashes, and anointing. Table 10 lists the actions to which Ælfric refers, grouped by category.

Table 10 - PATHOS: Physical Actions

\begin{tabular}{|l|l|}
\hline Para\# & \multicolumn{1}{|c|}{ PHYSICAL ACTION } \\
\hline 19 & Prostrate \\
\hline 30 & $\begin{array}{l}\text { the brothers shall prostrate themselves, making their confession to the abbot } \\
\text { psalms }\end{array}$ \\
\hline 34 & they shall perform the litanies prostrate \\
\hline 67 & they shall begin the seven psalms and finish these prostrate in choir \\
\hline 67 & $\begin{array}{l}\text { Then for the next seven days at the end of every [liturgical] hour they shall } \\
\text { prostrate themselves }\end{array}$ \\
\hline & Barefoot \\
\hline 34 & On Good Friday they should also go barefoot until the cross is venerated \\
\hline & Stand \\
\hline 9 & all standing except for those who are sick (for prayers during canonical hours) \\
\hline 42 & Then the deacon, standing with the ministers (Easter) \\
\hline 44 & Standing at the altar, the abbot shall say (Easter) \\
\hline & Kneel \\
\hline 29 & Kneeling - Ash Wednesday \\
\hline 33 & Maundy Tuesday \\
\hline 43 & Not kneeling - praying for treacherous Jews \\
\hline 61 & Let us kneel \\
\hline 43 & Genuflect \\
\hline
\end{tabular}

${ }^{98}$ D.G. Myers, Theories of Emotion, electronic version. 


\begin{tabular}{|c|c|}
\hline Para\# & PHYSICAL ACTION \\
\hline 49 & (Vespers of the Octave of Easter) we do not genuflect \\
\hline \multirow[t]{2}{*}{17} & (Vigil of Christ's Nativity) genuflect \\
\hline & Rise \\
\hline \multirow[t]{2}{*}{17} & (Vigil of Christ's Nativity) rise together \\
\hline & Sit \\
\hline 7 & The abbot shall sit in the cloister \\
\hline \multirow[t]{2}{*}{15} & Should the weather be mild, let them all sit together in the cloister \\
\hline & Washing Feet of paupers \\
\hline \multirow[t]{2}{*}{62} & $\begin{array}{l}\text { every day, in a place suited to this purpose, the brothers should take turns } \\
\text { washing the feet... of paupers }\end{array}$ \\
\hline & Ashes \\
\hline \multirow[t]{2}{*}{29} & $\begin{array}{l}\text { shall bless ashes and put them on the heads of each and every } \\
\text { person... because...human nature would return to dust, on account of guilt for } \\
\text { primordial transgression }\end{array}$ \\
\hline & Anoint \\
\hline 46 & $\begin{array}{l}\text { Because the Bishop should anoint on the forehead, where the high priest used } \\
\text { to wear a plate of gold }\end{array}$ \\
\hline 65 & Anointing \{of the sick\} with oil (on the first day only) \\
\hline
\end{tabular}

Ælfric reinforces his approach to eliciting an emotional response not only by emphasizing thoughts about suffering (e.g., Christ's death), but through the requirement of physical actions (such as prostration, kneeling or going barefoot). From a physiological theory approach, physical instructions to undertake certain bodily actions can result in, or affect, an emotional response. The interpretation by the brain of the emotional response to a physical reaction is often governed by the situations. For example, sweaty palms during an exam can be interpreted by the brain as anxiety, while sweaty palms during a date can be interpreted as love or anticipation.

Ælfric focusses on activities to be done either during the Passion (and Lent) or surrounding the illness and death of a monk. During the Passion, Ælfric refers twice to prostration, three times to going barefoot, three times to kneeling, twice to genuflecting, and once each for blessing with ashes and anointing. (Keep in mind that these are 
additional to any requirements for these actions in the Rule or in the Regularis

\section{Concordia.)}

For example, on Good Friday, the monks were to go barefoot until the cross was venerated, an act of humility, to mirror the suffering of Christ on that day. Good Friday can be as early as late March, and the weather in England in late March can be damp and cold, with temperatures around five degrees Celsius. This would not be pleasant weather in which to be walking barefoot on stone or earthen floors. This action is required in order to make the participant feel emotionally compromised, through physical means in this case, rather than through literature or through visual cues of paintings or illuminations.

In another example, the three days when the monks say the liturgy while prostrate (laying face-down on the floor) are Maundy Thursday, Good Friday and Holy Saturday of the Easter weekend. These are days leading up to and including the Crucifixion and Christ's sojourn in hell. The prostrate position is one that can be physically uncomfortable and taxing, and the emotions which might be associated with this are sadness, anxiety, or guilt. The act of prostration is not merely to create physical discomfort in order to evoke an emotional response, the posture itself is evocative of humility. It may also reflect the act of looking down into hell.

When talking about the death of a monk, he twice refers to prostration, once to kneeling and once to anointing. The reference to prostration, is underrepresented by the number 'twice', however, as Ælfric states that after the death of a monk, "for the next seven days at the end of every [liturgical] hour they shall prostrate themselves". This is a significant amount of discomfort to reinforce the emotional response to the death of a 
fellow monk. It may also be a way to handling grieving during this time period, by allowing the surviving monks to feel sorrow.

By using specific physical cues, Ælfric is eliciting a specific emotional response to a specific thought, in this case, the suffering and death of Christ. He establishes the link between Christ's sacrifice and the mortality of a monk through a physiological reaction that creates an emotional bond.

\subsection{Community}

Ælfric perceives a certain type of emotional community for the Benedictine monks, a sense of oneness. Table 11 shows the references to either doing activities together or individually.

\section{Table 11 - PATHOS: Community}

\begin{tabular}{|l|l|}
\hline Para\# & $\begin{array}{l}\text { Together* } \\
\text { "Together in the sense of people together, excludes the sense of the word } \\
\text { together related to' sing a psalm together with a prayer' }\end{array}$ \\
\hline 1 & together with his fellow bishops \\
\hline 2 & the children together as a group \\
\hline 7 & the abbot shall sit together with the brothers \\
\hline 9 & begin the Office together and finish it together \\
\hline 14 & let them all read and chant together in the domus... \\
\hline 14 & let them all sit together in the cloister \\
\hline 17 & all shall rise together \\
\hline 18 & two shall sing the responsory together \\
\hline 30 & $\begin{array}{l}\text { (if anyone wishes to venerate the cross in Lent, he has no need to venerate it } \\
\text { together with us on the day of the Lord's Passion) }\end{array}$ \\
\hline 34 & they shall chant the entire psalter together in choir \\
\hline 34 & They are to sing all the hours together \\
\hline Para\# & Individually \\
\hline 2 & the senior monks individually \\
\hline 34 & on Maundy Thursday they are to sing...the preces individually and silently \\
\hline 34 & $\begin{array}{l}\text { on Good Friday and } \text { \{Holy } \text { Saturday, \{they shall recite all the hours } \\
\text { individually and silently }\end{array}$ \\
\hline 45 & they shall individually sing the service of Vespers \\
\hline
\end{tabular}


In his instructions, Ælfric underscores the concept of community, by stating the number of things which the monks are to do together versus individually. On ten occasions, Ælfric states the requirement for monks or groups of monks to do certain activities together. The purpose of the requirement to do things together could be a matter of efficient operations, or it could have the intent is to breed harmony and to be of one accord. These actions range from reading, chanting and singing, to sitting, rising, beginning and ending together. Ælfric mentions children together, abbot and brothers together, bishops with fellow bishops. Doing activities together allows every member of the group to be involved with the actions of every other member. 


\section{Chapter 6: Are the Monks of Eynsham a Fictive Audience?}

In addition to investigating how Ælfric incorporated emotional rhetoric in his Letter, I was interested in how that rhetoric was disseminated. At a minimum, the target audience was the monks of Eynsham Abbey. Does the fact that Ælfric has couched the customary in the form of a letter give us a clue as to a broader audience?

\subsection{Significance of the Letter being a letter}

The Anglo-Saxon epistolary model, much like its continental counterpart, drew on Classical models of rhetoric requiring the presence of specific stages. A letter began with a salutatio (salutation) the form of address being elaborately fixed for each dignity and station in society: 'prescribed' with the recipient name first, 'subscribed' with the sender name first, and 'circumscribed', in which the recipient is named in several ways (for example, 'John, Archbishop of Rome, Pope of the holy Catholic church, pontiff over us all'). Next was the exordium (introduction) or captatio benevolentie (the grasping of goodwill), designed to put the reader in the right frame of mind and often consisting of a proverb or scriptural quotation. The body of the letter was the narratio (narrative or exposition). In closing was the petitia (petition), a request that was likely to take the form of a logical deduction from the major and minor premises already laid down in the exordium and narratio. The letter ended with the conclusio (conclusion). ${ }^{99}$

This epistolary style aided in the comprehension of a letter in two ways. Since medieval letters were meant to be read aloud, following the format was important so that the audience, learning Latin only as a second language, would know what to expect and

\footnotetext{
${ }^{99}$ Lancaster University, "Medieval Primary Sources, Genre Rhetoric and Transmission, HIST424, Seminar III: Letters and Letter Collections," accessed December 11, 2016, http://www.lancaster.ac.uk/staff/haywardp/hist424/seminars/03.htm.
} 
in what order. The format also aided the one who was reading the letter aloud, again, to know what to expect. Attention was given to the choice of a suitable vocabulary, the placing of words in an order that was pleasing to the mind and the ear, and to rhyme and cursus, metre of Latin, and cadences at ends of clauses. ${ }^{100}$

Ælfric's letter to his monks is often called a customary, as it lays out the specific liturgical customs he intended to be followed at Eynsham, but overall the text took the form of a letter, beginning with a typical salutation and finishing with a conclusion. That he wrote the monks a letter is an interesting point, as letters in the tenth century were not the secretive missives of today between a sender and a recipient. In the tenth-century, letters could be sent either as a closed letter (a breve clausum) which would have the sheets folded and bound using strings and wax seals, or as an open letter (a breve patens) which might have an impression of a seal at the foot of the page. ${ }^{101}$

Open letters were by far in the majority for two reasons. Letters in transit were often read out loud to others while en route to their designated recipients as a kind of entertainment that offered the wealthy an incentive to provide hospitality to their bearers. ${ }^{102}$ Alternately, correspondents, especially those engaged in the issues of the day, would often exploit public readings as a way of gaining publicity or support for their positions. ${ }^{103}$ So, one has to consider carefully whether the person to whom a letter is addressed does in fact comprise its sole, or even its primary, audience.

\footnotetext{
${ }^{100}$ Lancaster University, "Letters," accessed December 11, 2016, http://www.lancaster.ac.uk/staff/haywardp/hist424/seminars/03.htm 
This customary is a supplement to the Regularis Concordia. When Ælfric becomes Abbot of Eynsham in 1005, a customary is not something he would have just dashed off. Twenty pages of changes to various liturgical practices over the course of the church calendar would require some thought and time. He may have been contemplating and/or working on this document for some time while at Cerne Abbas. Equally possible, he could have written the customary upon his arrival at Eynsham, although this would beg the question of why one would write a letter to the monks with whom one was living. A monk such as Ælfric would be unlikely to waste parchment on a salutatio and conclusio if they were unnecessary.

\subsection{Possible routes for the Letter}

If we accept that this document is a letter and that it needed to travel from Cerne Abbas to Eynsham, how would the Letter get there? The role of messenger carrying a letter was more significant that just a delivery method. The messenger was often given oral instruction to accompany the letter. Indeed, the letter itself might be just an introductory mechanism, with the actual message entrusted orally to the messenger. ${ }^{104}$

The Letter could have been sent via a messenger, via a travelling monk, or carried by Ælfric himself as he journeyed from Cerne Abbas to Eynsham. As to the question of whether Ælfric would send the Letter by messenger or carry it himself, it seems unlikely that a new monastery would be populated with monks and operational prior to the arrival and oversight of the abbot. By carrying the Letter as an open letter, Ælfric would have been able to persuade at a number of monasteries along the way between Cerne Abbas

\footnotetext{
${ }^{104}$ Lancaster University, "Letters," accessed December 11, 2016, http://www.lancaster.ac.uk/staff/haywardp/hist424/seminars/03.htm.
} 
and Eynsham. If the Letter were carried either by a monk or by Ælfric, they would have been able to make use of monasteries along the way as points at which to stop over night.

The distance between Cerne Abbas and Eynsham is some 200 kilometres (124 miles) on today's roads. In 1005, the route would have been infinitely more treacherous and difficult. Little is known of the medieval road system apart from the Gough Map which appears to date from the middle of the fourteenth century. This shows main roads leading from London to Bristol via Reading, and from London to the far west of Cornwall via Guilford, Winchester, Shaftesbury and Exeter (sections of both roads represent Roman roads). ${ }^{105}$

To travel from Cerne Abbas to Eynsham, one would head east to Winchester before turning north to Oxford (although this route north would take one through the relatively unoccupied North Wessex Downs) or northwest towards Bath before turning east towards Eynsham. ${ }^{106}$

How long would such a journey take in 1005 CE? One way to estimate is by using the standards for measuring movement in the Roman world as outlined on The Stanford Geospatial Network Model of the Roman World, ORBIS, ${ }^{107}$ This website allows us to input the names of Roman sites to estimate the length of a journey when using Roman roads. A trip from Durnovia (Dorchester, just north of Cerne Abbas) through Aquae Sulis (Bath) then west to Spinis (Silchester ${ }^{108}$ ) gives a result of six days travel by foot. One would need to add another day to travel north to Oxford/Eynsham, which are not on the

\footnotetext{
${ }^{105}$ Martyn F. Wakelin, The Southwest of England (Amsterdam: John Benjamins Publishing, 1986), 9.

${ }^{106}$ Linguistics Geographies: The Gough Map of Great Britain, accessed December 12, 2016, http://www.goughmap.org/settlements/8113/.

${ }^{107}$ ORBIS: The Stanford Geospatial Network Model of the Roman World, accessed October 15, 2018, http://orbis.stanford.edu.

108 The ruins of Calleva Atrebatumare are near present-day Silchester.
} 
ORBIS mapping system. Similarly, a trip from Durnovia through Venta Belgarum (Winchester) to Spinis gives a result of five days travel by foot, plus one day north to Oxford/Eynsham. Travelling by horse could cut the travel time by approximately half (two and a half to three and a half days).

This assessment of the time needed for the trip from Cerne Abbas to Eynsham is reinforced by another method of estimating the length of the journey. We can look to The Canterbury Tales $^{109}$ for a trip of approximately 100 kilometres (63 miles) between London and Canterbury in the late 1300s. In Chaucer's day, a leisurely journey to Canterbury, with some pilgrims on horseback and some walking, took four days, with stops at inns along the way. April rains probably made the dirt road connecting Southwark and Canterbury muddy and rutted. Robbers were a constant danger on rural roads, however, armed pilgrims traveling in a large group, like those in The Canterbury Tales, probably were safe from marauders ${ }^{110}$. To go twice as far would take eight days. In 1005, either route had Benedictine monasteries at regular intervals which would welcome a travelling monk for the night. ${ }^{111}$ Along the route from Cerne Abbas via Bath to Eynsham, one would encounter three Benedictine monasteries along the way. Similarly, along the route from Cerne Abbas via Winchester to Eynsham, one would also encounter three Benedictine monasteries. The westerly route makes an arc from Cerne Abbas Abbey past Sherbourne through Glastonbury Abbey (32 miles) through Bath Abbey (25 miles) to Malmesbury Abbey (27 miles) to Eynsham (42 miles). The easterly

\footnotetext{
${ }^{109}$ Certain variables differ between a 1005 trip and the Canterbury Tales trip, including the condition of the roads, the speed of a large group versus a smaller group, etc., but the general comparison is useful to see if the calculations produce roughly similar results, which they do.

${ }^{110}$ Cummings Study Guide, "The Canterbury Tales", accessed December 11, 2016, http://www.cummingsstudyguides.net/Guides3/Canterbury.html.

${ }^{111}$ Knowles and Hadcock, Medieval Religious Houses, 58, 59, 62, 65, 66, 70, 74, 81.
} 
route makes an arc from Cerne Abbas Abbey via Milton Abbey (15 miles), Winchester (54 miles), Reading (35 miles), past Wallingford and Oxford to Eynsham (32 miles).

In summary, either the westerly route or the easterly route between Cerne Abbas and Eynsham were similar distances and would have taken some six to seven days walking, half that if on horseback, with stops available at various Benedictine monasteries along the way.

\subsection{Potential Audiences}

The Letter is addressed to the monks of Eynsham. Who were the monks of Eynsham? As Eynsham was a newly established abbey, the monks could have come from other abbeys, they could have been young oblates, or they could have been recruited from the population at large as postulants or novices. In the Letter, Ælfric states, “Because you have recently been ordained to the monastic habit at Æthelmær's request, you need to be instructed in monastic customs by both the spoken and written word"112. If they were newly chosen by Æthelmær, either as oblates or postulants/novices, how would they know enough about the Rule to understand the Letter? Ælfric also states, "dwelling with you I have observed"113, which leads one to think that he may have brought some monks with him from Cerne Abbas. While an average monk from Cerne Abbas would certainly have knowledge of the Rule and the Regularis Concordia, their opportunities to know the works of Amalarius would have been limited.

In summary, the monks Ælfric is addressing are ambiguous. As it is unclear as to who the primary audience is, might the letter be used to spread a larger or broader

\footnotetext{
${ }^{112}$ From the first paragraph of the Letter, the salutation. Christopher A. Jones, Alfric's Letter to the Monks of Eynsham, (Cambridge: Cambridge University Press, 1998), 111.

113 Ibid.
} 
message about monasticism? If Ælfric also had other audiences in mind, who might they be?

Other potential audiences could include: other abbots with whom he had studied at Winchester, and who oversaw abbeys along the route from Cerne Abbas to Eynsham, or in vicinity of Eynsham and/or Cerne Abbas; monks at those various Benedictine monasteries; bishops who respected his knowledge and ability well enough to have him draft letters for them; and, Æthelmær, the ealdorman who would live with the Eynsham community.

The intended audience must have been familiar with religious life. The letter assumes a close familiarity with the Rule of Saint Benedict and the Regularis Concordia. Ælfric's numerous references to Amalarius, in particular, require at a minimum that the reader recognize Amalarius’ reputation, if not be familiar with his writings. Ælfric’s Latinity, moreover, suggests an audience with a very good knowledge of Latin. The audience for this Letter must also have been knowledgeable as there are allusions to key figures in England and the Church (King Edgar, Saint Augustine, Pope Gregory, Amalarius, Æthelmær, Æthelwold), and to recent events (the bequeathing of the Eynsham Abbey, the drafting of Regularis Concordia). Ælfric's consistent use of logical argumentation, in addition to appeals to tradition and authority, also confirms an educated audience. The segment of society which would meet these parameters include monks, abbots and bishops educated in centres such as Winchester, educated ealdormen such as Æthelmær, and royalty such as King Æthelred.

The arguments presented in the Letter were those which would have resonated with Ælfric's colleagues from his formative years as a monk at Winchester Abbey. Those 
colleagues might still have been at Winchester, or might have since become abbots of various monasteries.

The bishops and archbishops for whom Ælfric drafted various letters, such as Wulfstan (between 1002 and $1005 \mathrm{CE}$ ) and Wulfsige (ca. $998 \mathrm{CE}$ ), would have been cognisant of the import of the references to which Ælfric was alluding in the Letter. Æthelmær was certainly educated and familiar with Latin. He may or may not have been familiar with the Rule and the Regularis Concordia. The tone of the Letter, one of service and humility, would certainly have been suitable in convincing superiors, religious or secular.

In the Letter, Ælfric makes a reference to the Rule, making an interesting statement saying that "no layman shall have dominion over any monastery where the holy Rule is observed, save the king alone" ${ }^{114}$. With respect to audience, one wonders to whom he is speaking? Is he speaking to Æthelmær, who will be living at the monastery? Ælfric may have been an opportunist, who used his new position as abbot as an opportunity to influence the Eynsham monks, and very possibly a broader audience, of his views on reform, writ large as to how a monk should behave.

\footnotetext{
${ }^{114}$ Letter, paragraph 63. Christopher A. Jones, AElfric's Letter to the Monks of Eynsham, (Cambridge:
} Cambridge University Press, 1998), 141. 


\section{Chapter 7: Conclusions}

Words crystalize culture. In Ælfric’s hands, the objective of a written customary is to define the lived actions of a monk. In analysing Ælfric's use of rhetoric, it is not the specific changes themselves that are necessarily of concern, rather it is the way he advocates for the changes that is key. Ælfric's use of logos rhetoric is relatively minimal relative to his use of ethos or pathos. This fact gives us insight into Ælfric's strategic use of rhetoric.

When we read the Letter today, we see and hear a laundry list of changes to a liturgical life. It appears to us as a dull, boring bureaucratic document. To really understand the impact of the Letter, we need to put ourselves in the mindset of the tenthcentury Benedictine monks who would be listening to the changes being proposed. For them, the elements of their daily, weekly, monthly routine create the framework of their lives. While we struggle to cope with the long litany of variations being proposed to routine, they would have comprehended immediately the impact of each change to the order of activities, to the name of psalm being recited, to the hymn being sung. It is little wonder that Ælfric couches his changes not in the bare logic of logos, or even the relative superiority of ethos, but rather in the persuasive and seductive use of pathos, of emotion.

Ælfric was, above all, an experienced educator. He would have known the best ways to convince his monks to accept and to adapt to the new customs he was proposing. Like modern marketers, rhetoricians since antiquity have understood that emotions were the quickest and surest way to bend the hearts of one's audience. Flfric was using the rhetoric and lexicon of his time to influence his future monks and incline them to his changes, perhaps in ways logical argument could not affect a very tradition-based 
identity. Amongst the details of changes to apparently minor monastic customs, Ælfric weaves an emotional discourse into seemingly dry instructions. Even though the Letter was meant to be a statement of restructured rules and duties, his language was designed to elicit an emotional response, both upon reading the Letter, and upon undertaking the stated actions. Animated discussion would arise amongst the monks at Eynsham Abbey or Winchester's Cathedral Abbey when this Letter was read aloud to the gathered congregation.

In his Letter, Ælfric characterizes the attributes of an ideal monk. The monk is humble, diligent, obedient and reverent. Ælfric emphasizes the sense of community through the number of activities done together versus those done individually, also the time when activities are done together (almost every day) versus when they are to be done individually (a few times around Easter). He also employs the use of 'norm power', to inculcate the social norms which will serve the interests and needs of members of the monastic society. Ælfric even demonizes outsiders (Jews), possibly in order to strengthen his idea of proper practice. Judas and Jews were particularly unworthy as they did not recognize Christ as the Son of God.

A significant portion (31 percent) of the Letter is spent focussing on the Passion/Easter, preaching Christ crucified, not Christ in majesty judging the quick and the dead. This heavy emphasis on Christ's suffering and Passion foreshadows the advent of affective piety in France some hundred years later. Ælfric also explicitly references the activities around the death of a monk, which emphasize mortality both of the monk who dies and of the monks who mourn, and thus the need to have the attributes upon which Ælfric focusses (humble, diligent, obedient, and reverent) in order to enter the Kingdom 
of Heaven. As Ælfric was some fifty years old when he drafted this letter, one wonders if he was foreshadowing his own impending death.

My study has raised several questions which I cannot fully address. We could seek to lay out further who were abbots of monasteries along possible routes between Cerne Abbas and Eynsham, or in the bishopric of Cerne Abbas or Eynsham, and thus, who belonged to Ælfric's social network and emotional community? Were they Winchester graduates who may have shared a common tutelage with Ælfric, and so been open to the changes he was suggesting in this customary?

Another course of action might be to compare the rhetoric in the Letter to other letters Ælfric wrote in early eleventh century, to see if they showed any indicators of the model of pathos/ethos/logos. An examination of other of Ælfric's work for words, choices of source material, choice of psalms/hymns, and suggested actions, could reveal indications of affective piety. Given that Ælfric was a prolific writer, this would be a large undertaking. An on-line tool, such as Voyant ${ }^{115}$, which can search for keywords, might be useful in analyzing large amounts of Ælfric's writing for word choice. The search could take place in the original Latin or in translation.

From a linguistic perspective, there is a dominance of West Saxon Dialect in Old Anglo Saxon English. Might this dominance be due to the efforts and prestige of King Alfred, or perhaps because the school of Æthelwold exercised control over linguistic usage and vocabulary? ${ }^{116}$

\footnotetext{
115 “Voyant Tools," Voyant, accessed March 29, 2016, http://voyant-tools.org/.

${ }^{116}$ Milton McC. Gatch, Preaching, 11.
} 
The fact that there were links between Cerne Abbas and Normandy might be instructive in devising a timeline for the early development of affective piety. ${ }^{117}$ Through her detailed study of John of Fécamp's writings and manuscript illuminations, Lauren Mancia has shown that the genesis of affective devotion occurred in the eleventh century (ca 1020-1030), far earlier than previously thought by scholars. ${ }^{118}$ It would be instructive to see if any of the writings of Ælfric had an impact on Fécamp documents.

\footnotetext{
${ }^{117}$ Both Winchester and Fécamp were significant Benedictine monasteries by $1005 \mathrm{CE}$, linked by strong political relationships of the day. Queen, Aelfigu-Emma, a witness to three various versions of the charter of Fécamp, was a daughter of Richard I and sister to Canute's contemporary Richard II, who re-established Fécamp in 1001. Fécamp held three manors in England, Rameslie, Steyning and Bury, all in Sussex. Charles H. Haskins, “A Charter of Canute for Fécamp,” The English Historical Review 33 (1918): 342. 118 Travis Stevens, "Devotion in the Medieval Monastery," review of Affective Devotion and Emotional Reform in the Eleventh-Century Monastery of John of Fécamp, by Lauren Elisabeth Mancia, Dissertation Reviews, February 9, 2015, http://dissertationreviews.org/archives/11462.
} 


\section{APPENDIX A}

\begin{tabular}{|c|c|}
\hline \multicolumn{2}{|c|}{$\begin{array}{c}\text { OVERVIEW OF THE WORKS OF FELRIC } \\
\text { (roughly in time sequence from } 987 \mathrm{CE} \text { to his death post } 1005 \mathrm{CE} \text { ) }\end{array}$} \\
\hline Document & Content \\
\hline $\begin{array}{l}\text { Two series of Catholic } \\
\text { Homilies }\end{array}$ & $\begin{array}{l}\text { Two books of forty discourses to be read aloud in church by } \\
\text { the clergy to the people on Sundays or Feasts in a liturgical } \\
\text { setting. The homilies provide paraphrases of the Gospel } \\
\text { readings for the day, and they expound the significance and } \\
\text { doctrines of those readings. As well as preaching, Flfric had } \\
\text { in mind individual readers as part of the target audience. }\end{array}$ \\
\hline $\begin{array}{l}\text { An English translation } \\
\text { of Bede's De } \\
\text { temporibus anni }\end{array}$ & (Early English Text Society) \\
\hline $\begin{array}{l}\text { Translations of two } \\
\text { sermons attributed to } \\
\text { Basil }\end{array}$ & $\begin{array}{l}\text { Hexameron (On the six days of creation), and the Admonitio } \\
\text { ad filium spiritualem }\end{array}$ \\
\hline Latin grammar & The first grammar in English, with Glossary \\
\hline Colloquy & An elementary instructional conversation \\
\hline Lives of Saints & Homilies and Old Testament paraphrases (39 chapters) \\
\hline $\begin{array}{l}\text { Translations of parts of } \\
\text { books of the Old } \\
\text { Testament }\end{array}$ & $\begin{array}{l}\text { Genesis, Judges, Kings, Joshua, Esther, Judith, Maccabees, } \\
\text { Numbers, Job }\end{array}$ \\
\hline $\begin{array}{l}\text { Compiled and issued a } \\
\text { new collection of } \\
\text { sermons }\end{array}$ & $\begin{array}{l}\text { Supplemental to the series published earlier, combining } \\
\text { revised versions of items from the Catholic homilies with } \\
\text { newly composed item }\end{array}$ \\
\hline $\begin{array}{l}\text { Pastoral letter on behalf } \\
\text { of Wulfsige, the bishop } \\
\text { of Sherborne }\end{array}$ & $\begin{array}{l}\text { In } 998 \text {, advice and instruction to the clergy of his diocese, in } \\
\text { which the Cerne abbey was situated }\end{array}$ \\
\hline Latin life of Æthelwold & \\
\hline $\begin{array}{l}\text { Revised and reissued } \\
\text { the first series of } \\
\text { Catholic Homilies, } \\
\text { some with new items }\end{array}$ & \\
\hline $\begin{array}{l}\text { Revised and extended } \\
\text { the temporale collection } \\
\text { of homilies }\end{array}$ & \\
\hline $\begin{array}{l}\text { Letter to the Monks of } \\
\text { Eynsham }\end{array}$ & $\begin{array}{l}\text { An augmentation for his own monks of Æthelwold's De } \\
\text { consuetudine monachorum }\end{array}$ \\
\hline $\begin{array}{l}\text { a letter to Wulfgeat of } \\
\text { Ylmandun }\end{array}$ & $\begin{array}{l}\text { Ylmandun has been identified with Ilmington, about thirty } \\
\text { miles from Eynsham. It begins with a six-line address to } \\
\text { Wulfgeat, in which Ælfric refers to former English writings, } \\
\text { lent to the thane, and to his promise to lend him more. Since } \\
\text { he calls himself abbot, and since in } 1006 \text { Wulfgreat fell into } \\
\text { disgrace and lost all his possessions, being supplanted by }\end{array}$ \\
\hline
\end{tabular}




\begin{tabular}{|c|c|}
\hline \multicolumn{2}{|c|}{$\begin{array}{l}\text { OVERVIEW OF THE WORKS OF ALFRIC } \\
\text { (roughly in time sequence from } 987 \mathrm{CE} \text { to his death post } 1005 \mathrm{CE} \text { ) }\end{array}$} \\
\hline Document & Content \\
\hline & $\begin{array}{l}\text { Eadric the famous traitor, the letter was evidently written in } \\
1005 \text { or } 1006\end{array}$ \\
\hline $\begin{array}{l}\text { Two pastoral letters for } \\
\text { Wulfstan, archbishop of } \\
\text { York and bishop of } \\
\text { Worcester } \\
\text { with Ælfric's reply in } \\
\text { Latin to a letter from } \\
\text { the archbishop } \\
\text { Wulfstan }\end{array}$ & $\begin{array}{l}\text { In Latin and English } \\
\text { Date likely initiated between } 1002 \text { and } 1005 \text {, with English } \\
\text { translation completed after } 1005\end{array}$ \\
\hline $\begin{array}{l}\text { Letter to Sigeweard, } \\
\text { layman }\end{array}$ & $\begin{array}{l}\text { Libellus de Veteri Testamento et Novo } \\
\text { Ælfric's response to a request from an Anglo-Saxon } \\
\text { nobleman, in part a review of Christian doctrine and in part a } \\
\text { review, book by book, of the Christian Bible, its meanings } \\
\text { and its contents on the Old and New Testaments, how to read } \\
\text { the Bible, three orders of society, laboratores, bellatores and } \\
\text { oratores, "drink more than I am used to" }\end{array}$ \\
\hline Letter to Sigefyrth & Deals with clerical celibacy \\
\hline \multicolumn{2}{|c|}{$\begin{array}{l}\text { Robert E. Bjork, “Ælfric," in The Oxford Dictionary of the Middle Ages, vol. 1, A-C (London: Oxford } \\
\text { University Press, 2010), 13. }\end{array}$} \\
\hline \multicolumn{2}{|c|}{$\begin{array}{l}\text { P.A. Clemoes, “The Chronology of Ælfric's Works”, in The Anglo-Saxons: Studies in some Aspects of } \\
\text { their History and Culture presented to Bruce Dickins, ed. P. Clemoes (London: Bowes and Bowes, } \\
\text { 1959), 212-47. }\end{array}$} \\
\hline \multicolumn{2}{|c|}{$\begin{array}{l}\text { Milton McC. Gatch, Preaching and Theology in Anglo-Saxon England: Elfric and Wulfstan (Toronto: } \\
\text { University of Toronto Press, 1977), 12-17. }\end{array}$} \\
\hline \multicolumn{2}{|c|}{$\begin{array}{l}\text { Joyce Hill, "Ælfric: His Life and Works," in A Companion to AElfric, eds. Hugh Magennis and Mary } \\
\text { Swan (Leiden, Netherlands: Brill, 2009), } 58 .\end{array}$} \\
\hline $\begin{array}{l}\text { Cambridge History of Engli } \\
\text { Beginnings to the Cycles of } \\
\text { accessed May 29, 2018, http }\end{array}$ & $\begin{array}{l}\text { ind American Literature in } 18 \text { Volumes (1907-21). Volume I. From the } \\
\text { ance. VII. From Alfred to the Conquest. 4. The Works of AElfric, }\end{array}$ \\
\hline
\end{tabular}




\section{BIBLIOGRAPHY}

\section{Primary Sources:}

Ælfric. First Old English Letter for Wulfstan (Prima epistola Anglice exposita). CCCC MS 190 Pages 320-336.

https://parker.stanford.edu/parker/actions/manuscript description long display.do?ms n $\underline{\mathrm{O}=190}$

Elfric. Letter to the Monks at Eynsham. Pages 237-257 in Cambridge, Corpus Christi College, Manuscript 265 (CCC MS 265), Wulfstan's Handbook and other ecclesiastical extracts.

https://parker.stanford.edu/parker/actions/manuscript_description_long_display.do?ms_n $\underline{0}=265$

Elfric. Preface to his Old English Letters to Wulfstan (Prologus venerabilis lfrici abbatis ad Wulstanum archiepiscopum). Page 320 in CCCC MS 90.

https://parker.stanford.edu/parker/actions/manuscript description long display.do?ms n $\underline{\mathrm{o}=190}$

Ælfric. Second Old English Letter for Wulfstan (Secunda epistola quando dividis crismam). CCCC MS 190 Pages 336-337.

https://parker.stanford.edu/parker/actions/manuscript_description_long_display.do?ms_n $\underline{\mathrm{o}=190}$

Amalar of Metz. On the Liturgy, Volume I, Books 1-2. Edited and translated by Eric Knibbs. Washington, D.C.: Dumbarton Oaks Medieval Library, 2014.

Aristotle. Rhetorica I.

http://www.perseus.tufts.edu/hopper/text?doc=Perseus:text:1999.01.0060:book=1:chapter $=2$ \&highlight $=$ emotion

Augustine. Adversus Iudaeos. Roger Pearce, trans, https://www.rogerpearse.com/weblog/2015/06/11/augustines-treatise-against-the-jews/comment-page-1/. Accessed June 18, 2018.

Augustine. De Doctrina Christiana, Book VI. In Augustine in his Own Words. Editor William Harmless. Washington, D.C.: CUA Press, 2010.

Augustine. Letter 93. Translated by J.G. Cunningham. From Nicene and Post-Nicene Fathers, First Series, Vol. 1. Edited by Philip Schaff. (Buffalo, NY: Christian Literature Publishing Co., 1887.) Revised and edited for New Advent by Kevin Knight. http://www.newadvent.org/fathers/1102093.htm. Accessed October 16, 2018.

Cicero, Orator, LCL 342. https://www.loebclassics.com/view/marcus tullius ciceroorator/1939/pb LCL342.299.xml

Regularis Concordia. CCCC MS 201 (Cotton MS Tiberius Aiii), The British Library. (This manuscript has a copy of the Regularis Concordia and the Rule.) http://www.bl.uk/onlinegallery/onlineex/illmanus/cottmanucoll/r/011cottiba00003u00003 $\underline{000 . h t m l}$ 
Rule of Saint Benedict. Harley MS 5431, The British Library.

http://www.bl.uk/manuscripts/FullDisplay.aspx?ref=Harley MS 5431 (Other versions include: Harley MS 948, Rule of St Benedict, which dates from the second half of the 12th century; Old English translations of the Rule are found in two Cotton manuscripts (Titus A IV, Faustina A X part B), and there is a Latin-Middle English bilingual version in another (Claudius D III).)

\section{Secondary Sources:}

“Anicius Manlius Severinus Boethius." In Stanford Encyclopedia of Philosophy, last modified July 19, 2016. https://plato.stanford.edu/entries/boethius/.

Bann, Stephen. The Inventions of History: Essays on the Representation of the Past. Manchester: Manchester University Press, 1990.

Bateson, Mary. "Excerpta ex Institutionibus Monasticis AEthelwoldi Episcopi Wintoniensis Compilata in usum Fratrum Egneshamnensium per Ælfricum Abbatem." Compotus Rolls of the Obedientiaries of St. Swithun's Priory, Winchester, edited by G. W. Kitchin, Hampshire Record Society 7. London: Simpkin/Winchester: Warren, 1892.

Bedingfield, M. Bradford. The Dramatic Liturgy of Anglo-Saxon England (Aethelstan, Dunston, Oswald, Burford, AElfric, Wulfstan Cantor, Wulfstan of York). Woodbridge, Suffolk: The Boyden Press, 2002.

Bedingfield, M. Bradford. "Ritual and Drama." In Liturgy of the Late Anglo-Saxon Church, edited by Helen Gittos and M. Bradford Bedingfield, 299-317. Woodbridge, Suffolk: Boydell Press, 2005.

Bellenger, Aidan. "A medieval novice's formation." In Medieval Monastic Education, edited by George Ferzoco and Carolyn Muessig, 35-40. London: Leicester University Press, 2000.

Beltramo, Silvia. "Medieval Architecture for Religious Tourism and Hospitality along the Pilgrimage Routes of Northern Italy." International Journal of Religious Tourism and Pilgrimage 3 (2015): 78-94.

https://arrow.dit.ie/cgi/viewcontent.cgi?article=1042\&context=ijrtp.

Bennett, Judith M. Early Medieval Europe. New York: McGraw-Hill, 2011.

Bjork, Robert E. “Ælfric”. In The Oxford Dictionary of the Middle Ages, vol. 1, A-C. London: Oxford University Press, 2010.

British History Online. "Houses of Benedictine Monks, The Abbey of Eynsham". Accessed December 10, 2016. http://www.british-history.ac.uk/vch/oxon/vol2/pp65-67

British Library Online Gallery. "Regularis Concordia." Last modified 26 March 26, 2009.

http://www.bl.uk/onlinegallery/onlineex/illmanus/cottmanucoll/r/011 cottiba00003u00003 000.html. 
Cambridge History of English and American Literature in 18 Volumes (1907-21). Volume I. From the Beginnings to the Cycles of Romance. VII. From Alfred to the Conquest. 4. The Works of Ælfric. http://www.bartleby.com/211/0704.html Accessed May 29, 2018.

Carpenter, David X. EYNSHAM ABBEY Benedictine abbey of St Mary, St Benedict, \& All Saints County of Oxford: Diocese of Lincoln Founded 1005; perhaps refounded c.1095. Charters of William II and Henry I Project, University of Oxford, 2016.

Cannago, Michael. Essays on Medieval Rhetoric. Farnham: Ashgate Variorum, 2012.

Carruthers, Mary, ed. Rhetoric Beyond Words: Delight and Persuasion in the Arts of the Middle Ages. Cambridge: Cambridge University Press, 2010

Clemoes, Peter. "The Chronology of Ælfric's Work.” In The Anglo-Saxon: Studies in Some Aspects of their History and Culture, edited by Peter Clemoes, 212-247. London: Bowes and Bowes, 1959.

Clemoes, Peter ed. Anglo-Saxon England 3. Cambridge: Cambridge University Press, 1974.

Clemoes, Peter and Kathleen Hughes, eds. England before the Conquest. Cambridge: Cambridge University Press, 1971.

Conley, Thomas. Rhetoric in the European Tradition. Chicago: University of Chicago Press, 1990.

Copeland, Rita. "Medieval Rhetoric." In Encyclopedia of Rhetoric, edited by Thomas O. Sloane, electronic version. Oxford: Oxford University Press, 2001.

Corona, Gabriella. "Ælfric's Schemes and Tropes: Amplificatio and the Portrayal of Persecutors." In A Companion to Alfric, edited by Hugh Magennis and Mary Swan, 297320. Leiden, Netherlands: Brill, 2009.

Cummings Study Guide. "The Canterbury Tales". Accessed December 11, 2016. http://www.cummingsstudyguides.net/Guides3/Canterbury.html

Davis, Graeme. The Word Order of Alfric. Lewiston, New York: Edwin Mellon Press, 1977.

Davis, Kathleen. "Boredom, Brevity and Last Things: Ælfric's style and the politics of time." In A Companion to Alfric, edited by Hugh Magennis and Mary Swan, 321-344. Leiden, Netherlands: Brill, 2009.

DeGregorio, Scott, ed. The Cambridge Companion to Bede. Cambridge University Press: Cambridge, 2010.

Dumville, David N. Liturgy and the Ecclesiastical History of Late Anglo-Saxon England: Four Studies. Woodbridge, Suffolk: The Boydell Press, 1992.

Eynsham Online. "Eynsham Abbey.” Accessed December 10, 2016. http://eynshampc.gov.uk/org.aspx? $n=$ Eynsham-Heritage\&id=287. 
Forbes, Helen Foxhall. "Affective piety and the practice of penance in late eleventhcentury Worcester: the address to the penitent in Oxford, Bodleian Library, Junius 121." Durham Research Online, Durham University. Accessed April 1, 2017. http://dro.dur.ac.uk/16699/1/16699.pdf?DDD17+tqkv18+d700tmt. Originally published in Anglo-Saxon England, 44, 2015, 309-345.

English Oxford Living Dictionaries. "Emotion." "Passion.” Accessed November 3, 2018. https://en.oxforddictionaries.com/definition/emotion.

Gatch, Milton McC. Preaching and Theology in Anglo-Saxon England: Alfric and Wulfstan. University of Toronto Press: Toronto, 1977.

Giles, J.A. Old English chronicles: including Ethelwerd's chronicle, Asser's Life of Alfred, Geoffrey of Monmouth's British history, Gildas, Nennius, together with the spurious Chronicle of Richard of Cirencester. London: G. Bell, 1906.

Godden, Malcolm. "Flfric of Eynsham." Oxford Dictionary of National Biography. Accessed September 19, 2016.

http://www.oxforddnb.com/view/10.1093/ref:odnb/9780198614128.001.0001/odnb9780198614128-e-187; jsessionid=7D4FAAA7ABC1BE0C81AFA605DA7ECA60.

Godden, Malcolm, ed. Alfric's Catholic Homilies: The Second Series. EETS, SS 5. London: Oxford University Press, 1979.

Godden, Malcolm, ed. Alfric's Catholic Homilies: Introduction, Commentary and Glossary. EETS, SS 18. London: Oxford University Press, 2000.

Gneuss, Helmut. AElfric of Eynsham: His Life, Times and Writings. Kalamazoo: Medieval Institute Publications, Western Michigan University, 2009.

Griffith, Mark. "Flfric's Preface to Genesis: Genre, Rhetoric and the origins of the 'ars dictaminis'," Anglo-Saxon England, Volume 29 (2000): 215.

Haskins, Charles H. "A Charter of Canute for Fécamp." The English Historical Review 33 (1918): 342-344.

Higham, Nicholas J., and Martin J. Ryan. The Anglo-Saxon World. New Haven: Yale University Press, 2015.

Hill, Joyce. Ælfric in "Gregory and the Carolingians." Oxford Biographies.com. http://www.oxfordbibliographies.com/view/document/obo-9780195396584/obo9780195396584-0157.xml

Hill, Joyce. “Ælfric: His Life and Works.” In A Companion to Alfric, eds. Hugh Magennis and Mary Swan, XX-XX. Leiden, Netherlands: Brill, 2009.

Hill, Joyce. "Rending the Garment and Reading by the Rood: Regularis Concordia Rituals for Men and Women." In Liturgy of the Late Anglo-Saxon Church, edited by Helen Gittos and M. Bradford Bedingfield, 53-64. Woodbridge, Suffolk: Boydell Press, 2005. 
Hogel, Christian and Elisabetta Bartoli. Medieval Letters: Between Fiction and Document. Turnhout, Belgium: Brepols, 2015.

Hogg, Richard. An Introduction to Old English. Great Britain: Edinburgh University Press, 2002.

Hurt, James. AElfric. New York: Twayne Publishers Inc., 1972.

Jayatilaka, Rohini. “Alfric's Letter to the Monks of Eynsham.” Review of AElfric: Letter to the Monks of Eynsham, by Christopher A. Jones, The Free Library by Farlex, 2000.

Jones, Christopher A. Alfric's Letter to the Monks of Eynsham. Cambridge: Cambridge University Press, 1998.

Jones, Christopher. "Ælfric and the Limits of 'Benedictine Reform." In A Companion to Alfric, edited by Hugh Magennis and Mary Swan, 67-108. Leiden, Netherlands: Brill, 2009.

Jorgensen, Alice. "Historicizing Emotion: The Shame-Rage Spiral in Ælfric's Life of St Agatha." English Studies 93, no. 5 (July 2012): 529-538.

Karkov, Catherine E. The Ruler Portraits of Anglo-Saxon England (Anglo-Saxon Studies 3). Woodbridge, Suffolk: Boydell Press, 2004.

Keefer, Sarah Larratt. "Veneration of the Cross in Anglo-Saxon England." In Liturgy of the Late Anglo-Saxon Church, edited by Helen Gittos and M. Bradford Bedingfield, 143184. Woodbridge, Suffolk: Boydell Press, 2005.

Kempshall, Matthew S. "The virtues of rhetoric: Alcuin's "Disputalo de rhetorica et de uirtutibus"." Anglo-Saxon England 37 (2008): 7-30.

Kleist, Aaron J. Striving With Grace: Views of Free Will in Anglo-Saxon England. Toronto: University of Toronto Press, 2008. Kindle edition.

Knowles, David, and R. Neville Hadcock. Medieval Religious Houses; England and Wales. London: St. Martin's Press, 1972.

Lancaster University. "Medieval Primary Sources, Genre Rhetoric and Transmission, HIST424, Seminar III: Letters and Letter Collections.” Accessed December 11, 2016. http://www.lancaster.ac.uk/staff/haywardp/hist424/seminars/03.htm

Lawrence, C.H. Medieval Monasticism: forms of religious life in Western Europe in the Middle Ages. Harlow, England and New York: Longman, 1989.

Lemmings, David and Ann Brooks, ed., Emotions and Social Change: Historical and Sociological Perspectives. New York: Routledge, 2014.

Leyser, Henrietta. A Short History of the Anglo-Saxons. I.B.Tauris: New York, 2016.

Linguistics Geographies: The Gough Map of Great Britain. Accessed December 12, 2016. http://www.goughmap.org/settlements/8113/. 
Lockett, Leslie. Anglo-Saxon psychologies in the Vernacular and Latin Traditions. Toronto: University of Toronto Press, 2011.

Mack, Peter. "Argument and Emotion in Troilus and Criseyde." In Medieval Rhetoric: A Casebook, edited by Scott D. Troyan, 109-126. New York: Routledge, 2004.

Magennis, Hugh and Mary Swan, eds. A Companion to Alfric. Leiden, Netherlands: Brill, 2009.

Mancia, Lauren. "Affective Devotion and Emotional Reform in the Eleventh-Century Monastery of John of Fécamp.” PhD diss., Yale University, 2013.

Marsden, Richard. The Cambridge Old-English Reader. Cambridge: Cambridge University Press, 2015.

Matt, Susan J. "Recovering the Invisible: Methods for the Historical Study of the Emotions." In Doing Emotions History, edited by Susan J Matt and Peter N. Stearns. Chicago: University of Illinois Press, 2014.

McNamer, Sarah. Affective Mediation and the Invention of Medieval Compassion. Philadelphia: University of Pennsylvania Press, 2010.

McWilliams, Stuart, ed. Saints and Scholars: New Perspectives on Anglo-Saxon Literature and Culture in Honour of Hugh Magennis. Cambridge: D.S. Brewer, 2012.

Mensah, Marthe and Fabienne Toupin. La Grammaire d'Elfric: traduction et commentaire linguistique. Paris: AMAES, 2005.

Millett, Bella. "Change and Continuity - The English Sermon before 1250." In The Oxford Handbook of Medieval Literature in English, edited by Elaine Treharne and Greg Walker, 223. New York: Oxford University Press, 2010.

Murphy, James J. Medieval Rhetoric: A Select Bibliography. Toronto: Centre for Medieval Studies, University of Toronto Press, 1971.

Murphy, James J. Medieval Eloquence: Studies in the Theory and Practice of Medieval Rhetoric. Berkeley: University of California Press, 1978.

Murphy, James J. Rhetoric in the Middle Ages: A History of Rhetorical Theory from Saint Augustine to the Renaissance. Berkeley: University of California Press, 1974.

Murphy, James J., ed. Three Medieval Rhetorical Arts. Berkeley: University of California Press, 1971.

Myers, D.G. Theories of Emotion. Psychology: Seventh Edition. New York, NY: Worth Publishers, 2004, electronic version.

Nocent, Hadrianus. Consuetudimun Saec. Ed. Kassius Hallinger, Corpus Cons. Mon. 7.3, 149-185. Siegburg, 1984.

http://www.thefreelibrary.com//Elfric's+Letter+to+the+Monks+of+Eynsham.a064976146. 
Online Etymology Dictionary. "Emotion.” Passion.” Accessed October 31, 2018. https://www.etymonline.com/word/emotion. https://www.etymonline.com/word/passion.

ORBIS: The Stanford Geospatial Network Model of the Roman World. Accessed October 15, 2018. http://orbis.stanford.edu.

Oxford American Writer's Thesaurus. New York: Oxford University Press, 2012.

Perelman, Les. "The Medieval Art of Letter Writing - Rhetoric as Institutional Expression." In Textual Dynamics of the Professions: Historical and Contemporary Studies of Writing in Professional Communities, edited by Charles Bazerman and James Paradis, 97-119. Originally Published in Print, Madison, Wisconson: University of Wisconsin Press, 1991. Electronic Publication, 2004. https://wac.colostate.edu/books/textual dynamics/chapter4.pdf

Accessed April 1, 2017.

Pfaff, Richard W. The Liturgy in Medieval England: A History. New York: Cambridge University Press, 2009.

Reinsma, Luke M. Alfric: an annotated Bibliography. New York: Garland Publishing, 1987.

Reuter, Timothy, ed. The New Cambridge Medieval History, vol. III c900-1024. Cambridge: Cambridge University Press, 1999.

Rosenwein, Barbara. Emotional Communities in the Early Middle Ages. Ithaca: Cornell University Press, 2006.

Rosenwein, Barbara. "Thinking Historically about Medieval Emotions," History Compass 8.8 (2010): 828-842.

Reynolds, Suzanne. Medieval Reading: Grammar, Rhetoric, and the Classical Text. Cambridge: Cambridge University Press, 1996.

Salter, Herbert Edward. Eynsham Cartulary. Oxford: Clarendon Press, 1907. https://archive.org/details/eynshamcartular00saltgoog.

Scheil, Andrew. “Ælfric of Eynsham.” Oxford Handbooks Online. September, 2014. http://www.oxfordhandbooks.com/view/10.1093/oxfordhb/9780199935338.001.0001/oxf ordhb-9780199935338-e-54.

Stanton, Robert. "Rhetoric and Translation in Ælfric's Prefaces," Translation and Literature, Volume 6, Issue 2 (1977): 135-148.

Stanford's Digital Manuscript Index. "Cambridge, Corpus Christi College, Parker Library, CCCC MS 265”. Accessed December 10, 2016. http://dms.stanford.edu/catalog/CCC265 keywords

Stanford Libraries. Parker Library On the Web. Manuscripts In the Historic Parker Library at Corpus Christi College, Cambridge. MS 265: Wulfstan's Handbook and other ecclesiastical extracts. Accessed October 23, 2018. 
https://parker.stanford.edu/parker/catalog/nh277tk2537

Swain, Larry J. Alfric of Eynsham's Letter to Sigeweard: An edition, Commentary and Translation. Electronic copy. Witan Publishing, 2017.

https://books.google.ca/books?id=jxLRDgAAQBAJ\&printsec=frontcover\&source=gbs_g e_summary $\mathrm{r} \& \mathrm{cad}=0 \# \mathrm{v}=$ onepage $\& \mathrm{q} \& \mathrm{f}=$ false

Swan, Mary. "Identity and Ideology in Ælfric's Prefaces." In A Companion to Elfric, edited by Hugh Magennis and Mary Swan, 247-269. Leiden, Netherlands: Brill, 2009.

Symons, Dom Thomas, trans. Regularis Concordia, Anglicae Nationis Monachorum Sanctimonialiumque - The Monastic Agreement of the Monks and Nuns of the English Nation. London: T. Nelson and Sons, 1953.

Thagard, Paul. "Power and Emotion." Psychology Today. August 2016, internet copy. Accessed June 13, 2018. https://www.psychologytoday.com/us/blog/hotthought/201608/power-and-emotion.

The Voice: Christian Resource Institute. "Structure, Genre, and Theology in Psalms." Accessed March 29, 2016. http://www.crivoice.org/psalmgenre.html

Stevens, Travis. "Devotion in the Medieval Monastery." Review of Affective Devotion and Emotional Reform in the Eleventh-Century Monastery of John of Fécamp, by Lauren Elisabeth Mancia. Dissertation Reviews, February 9, 2015. http://dissertationreviews.org/archives/11462.

Tupper, Jr., Frederick. "History and Texts of the Benedictine Reform of the Tenth Century." Modern Language Notes 8 (1893): 344-367.

University of California, Davis. James J. Murphy, trans. "Anonymous of Bologna: The Principles of Letter-Writing (Rationes dictandi)." Accessed December 11, 2016. http://medieval.ucdavis.edu/20B/Ars.Dictandi.html

University of Toronto. “Ælfric: The Letters, Cambridge, Corpus Christi College, MS 265, pp. 3-208." Accessed on December 10, 2016.

http://groups.chass.utoronto.ca/ÆElfric/MSC.html.

University of Toronto. "All about Emotional Intelligence.” Accessed October 23, 2018. http://psych.utoronto.ca/users/reingold/courses/intelligence/cache/about ei.htm.

Wakelin, Martyn F. The Southwest of England. Amsterdam: John Benjamins Publishing, 1986.https://books.google.ca/books?id=OxV3QsevHoEC\&pg=PA9\&lpg=PA9\&dq=dista $\underline{\text { nce }+ \text { cerne }+ \text { abbas }+ \text { dorset }+ \text { to }+ \text { ox ford }+ \text { in }+ \text { medieval \&source }=\text { bl\&ots }=J p C N 3 M F o z-}$

\&sig=AoSXidi0xfudtRFVJPAxxpAe NE\&hl=en\&sa=X\&ved=0ahUKEwj12f66geXQAh UJ62MKHYqXBW0Q6AEIJzAC\#v=onepage \&q=distance $\% 20$ cerne $\% 20$ abbas $\% 20$ dorse t $\% 20$ to $\% 20$ oxford $\% 20$ in $\% 20$ medieval $\& \mathrm{f}=$ false

White, Caroline Louisa, Ph.D. Alfric: A New Study of his Life and Writings. Boston, New York, and London: Lamson, Wolfee and Company, 1898. Accessed December 11, 2016.

https://archive.org/stream/Ælfricnewstudyo00whituoft/Ælfricnewstudyo00whituoft djvu. txt. 
Yerkes, David. Strayer, Joseph R., ed. Dictionary of the Middle Ages, vol. 1, AachenAugustinism, “Ælfric.” New York: Scribner, c1982-c1989.

Yerkes, David. "Fifty-Six Ælfric Fragments: The Newly-Found Copenhagen Fragments of Ælfric's ‘Catholic Homilies’ with Facsimiles.” Speculum 63 (1988): 890.

Zweck, Jordan. Epistolary Acts: Anglo-Saxon Letters and Early English Media. Toronto: University of Toronto Press, 2018. 